\title{
Structure and Mechanical Properties of Fe-Ni-Zr Oxide-Dispersion-Strengthened (ODS) Alloys
}

K.A. Darling ${ }^{1 *}$, M. Kapoor ${ }^{2}$, H. Kotan ${ }^{3}$, B.C. Hornbuckle ${ }^{1}$, S.D. Walck ${ }^{1}$, G.B. Thompson ${ }^{2}$, M.A. Tschopp ${ }^{1}$, and L.J. Kecskes ${ }^{1}$

${ }^{1}$ U.S. Army Research Laboratory, Weapons and Materials Research Directorate, Aberdeen Proving Ground, MD 21005-5069, USA

${ }^{2}$ The University of Alabama, Department of Metallurgical \& Materials Engineering Tuscaloosa, AL USA 35487-0202

${ }^{3}$ Necmettin Erbakan University, Department of Metallurgical \& Materials Engineering, Konya, 42090, Turkey

\section{Abstract}

A series of bulk nanostructured Fe-Ni-Zr oxide-dispersion-strengthened (ODS) alloys were synthesized using high energy mechanical alloying and consolidated using high temperature equal channel angular extrusion. The resultant microstructures are composed of nano/ultrafine or micrometer-sized grains with larger intermetallic precipitates and small $\mathrm{Zr}$ oxide clusters $(<10 \mathrm{~nm}$ diameter, measured and confirmed by atom probe tomography). The ODS alloys possess elevated compression properties, e.g., 1.2 and 2.4 GPa compressive yield stress at room temperature for samples consolidated at $700{ }^{\circ} \mathrm{C}$ and $1000{ }^{\circ} \mathrm{C}$, respectively. This work highlights the relationship between processing, microstructure, and properties for this class of ferritic ODS alloys.

\section{Keywords}

Mechanical properties, Oxide-dispersion-strengthening, Atom Probe Tomography, Fe based ODS alloys, Zirconium-oxide 


\section{Corresponding Author Contact info}

* Kristopher Allen Darling

Phone number: $\quad$ 410-306-0862

Fax number: 410-306-1407

Email: $\quad$ Kristopher.darling.civ@ mail.mil 


\section{Introduction}

Oxide-dispersion-strengthened (ODS) Fe-based alloys designed for next generation nuclear reactors exhibit outstanding strength, creep, and fatigue properties as well as high irradiation resistance and thermomechanical stability [1-12]. One avenue for improving the current state of the art relies on producing and engineering the precipitation of nanoscale oxide particles or clusters within the matrix of the alloy. This has typically been accomplished by utilizing high energy mechanical alloying, a farfrom-equilibrium processing method, which is well known for creating metastable solid solutions and nano-particle dispersions at the finest length scales [13, 14].

Research on ODS Fe-based alloys employing high energy mechanical alloying has largely focused on engineering alloys containing an ultra-high density of $\mathrm{Y}$ - or $\mathrm{Y}$-Tibased oxide features [15-33]. In such cases, $\mathrm{Ti}$ is typically used as an oxide refining agent $[15-17,20,21,25,26,28,30-33]$, but in a few exceptions Ti has been replaced by $\mathrm{Al}$ or other transition metals for the same purpose [18, 22, 23, 24]. During mechanical alloying, the controlled use of these additions, whether in oxide or metallic form and the extent to which they are dissolved in the Fe matrix, represents an active area of current research [33]. However, subsequent heat treating of these dissolved additions causes decomposition/interaction to form complex nanoscale oxides greater than $5 \mathrm{~nm}$ and/or coherent oxide clusters with diameters less than 2-5 nm. These oxides and oxide clusters are heavily dispersed throughout the Fe matrix and are in part responsible for the high strength and unique properties reported recently [34]. 
While oxides based on $Y$ have been heavily researched, oxides based on group IV elements such as $\mathrm{Zr}$ have not [35-36]. As such, utilizing $\mathrm{Zr}$ as a basis within ODS alloys may provide an alternative path for developing properties in ODS alloys for the following four reasons: 1) Zr has a great affinity for oxygen (to produce the oxide phase) $[37,38], 2) \mathrm{Zr}$ oxides have higher melting temperatures than $\mathrm{Y}$ oxides (perhaps greater thermal stability) [37], 3) Zr atoms have a low mobility due to the large atomic mismatch in Fe and form a meta-stable solid solution [39-42] (helping to disperse and also slowing subsequent coarsening [36]), and 4) doping zirconia with $\mathrm{Fe}$, as a result of mechanical alloying, has been shown to stabilize the high temperature cubic phase [43-48], which allows resizing its unit cell to increase the likelihood of attaining coherency with the Fe matrix [43-48], a prerequisite to resisting the high temperature coarsening of the oxide particles.

For all these reasons, alternative oxides based on group IV elements are an intriguing possibility for engineering the properties of ODS alloys. However, it still remains to be seen how readily $\mathrm{Zr}$-based oxides can be formed and whether or not $\mathrm{Zr}$ based ODS alloys enhance properties similar to that observed in conventional $\mathrm{Y}$ - or $\mathrm{Y}$ Ti-based alloys.

In this paper, we report the formation of $\mathrm{Zr}$-based ODS Fe alloys through the combination of high energy mechanical alloying and consolidation at elevated temperatures via equal channel angular extrusion (ECAE). The resultant microstructures, being dependent on consolidation temperature, were composed of 
nano/ultra-fine or micrometer-sized grains with Zr-rich intermetallic precipitates (submicrometer diameter) and small (less than $10 \mathrm{~nm}$ diameter) Zr-based oxide clusters. In turn, the Fe-Ni-Zr ODS alloys, demonstrated impressive compressive yield stresses of $\sim 2400 \mathrm{MPa}, \sim 1600 \mathrm{MPa}$, and $\sim 600 \mathrm{MPa}$ measured at room temperature (RT), $400{ }^{\circ} \mathrm{C}$, and $600^{\circ} \mathrm{C}$, respectively. The mechanical compressive properties were then linked to structure, chemistry, and processing through the use of atom probe tomography (APT), transmission election microscopy (TEM), scanning transmission electron microscopy (STEM) and ion channeling contrast imaging.

\section{Materials and Methods}

\subsection{Mechanical Alloying and Consolidation}

The Fe-8Ni-4Zr (at.\%) alloys were synthesized by high energy mechanical alloying in a SPEX 8000D shaker mill. The appropriate amounts of $\mathrm{Fe}, \mathrm{Ni}$, and $\mathrm{Zr}$ starting powders (Alfa Aesar, Ward Hill, MA), which were -325 mesh and 99.9\%, 99.8\%, and $99.5 \%$ pure, respectively, with a total weight of $10 \mathrm{~g}$ were loaded into hardened steel vials (SPEX model 8007) along with milling media (440C stainless steel balls) at a ball-to-powder ratio of 10 -to- 1 by weight, and then sealed inside a glove box containing Ar atmosphere (oxygen and moisture are less than $1 \mathrm{ppm}$ ). Room temperature ball milling was carried out at 950 revolutions per minute for a total of 20 hours. No processing agents such as sodium chloride, stearic acid, or other organics were utilized. After milling, the vials were again placed inside the glove box and the powders removed and stored until enough consecutive milling runs were completed, thereby generating enough powder (approximately $250 \mathrm{~g}$ ) for the consolidation experiments. In general, 
the powders were un-agglomerated having individual particle sizes between $10 \mu \mathrm{m}$ and $100 \mu \mathrm{m}$. X-ray diffraction studies revealed the as-milled powder to have a microstructure consisting of a Fe-Ni-Zr supersaturated body centered cubic (BCC) solid solution having an average matrix grain size of $\sim 10 \mathrm{~nm}$.

For the ECAE consolidation experiments, the as-milled powders were placed into nickel cans and sealed inside the glove box. The cans were created by taking billets of nickel 201 alloy having dimensions of $25.4 \mathrm{~mm} \times 25.4 \mathrm{~mm} \times 90 \mathrm{~mm}$ and boring a 10$\mathrm{mm}$ diameter hole (approximately $50 \mathrm{~mm}$ long) along the long axis of the billet. This created a chamber for placing the as-milled Fe-Ni-Zr powders. Once loaded, the powder chamber was sealed shut by placing a press fit nickel plug into the top of the ECAE bill through the initial channel hole and physically upsetting it to create an air sight seal. Prior to ECAE processing, the die assembly was heated to $300{ }^{\circ} \mathrm{C}$. The nickel cans loaded with as-milled powders were equilibrated (for $40 \mathrm{~min}$ ) in a box furnace purged with pure Ar gas at the respective temperatures $700,800,900$, and $1000{ }^{\circ} \mathrm{C}$, respectively. The equilibrated cans were then quickly removed from the furnace, dropped into the ECAE tooling and extruded at an extrusion rate of $25.4 \mathrm{~mm} \mathrm{~s}^{-}$ 1. The extrusion procedure was repeated four times following route $B_{c}[49]$. The ECAE tooling had an $\mathrm{L}$ shaped channel $(254 \mathrm{~mm}$ high $\times 177.8 \mathrm{~mm}$ long with a cross sectional dimension of $482.6 \mathrm{~mm}^{2}$ ) meeting at an angle of $90^{\circ}$. The four consecutive extrusions per sample resulted in a total equivalent strain of $464 \%$. A part of the extruded cans were then either serial sectioned for microstructural characterization or cut into compression samples using wire electric discharge machining using an E-pack setting of \# 942. Compression samples were cylinders with $3 \mathrm{~mm}$ diameter and height and 
$\pm 10 \mu \mathrm{m}$ tolerances in all dimensions.

The required consolidation temperatures enter into a regime on the equilibrium phase diagram where a ferrite-austenite phase transformation is expected in the Fe-Ni-Zr system. To examine this, $\mathrm{X}$-ray diffraction was performed at multiple temperatures (from room temperature up to the highest consolidation temperature of $1000^{\circ} \mathrm{C}$ ) to examine the phase transformation from BCC (ferrite) to FCC (austenite) in the as-milled powders. At temperatures equivalent to the consolidation temperatures, the presence of both BCC (ferrite) and FCC (austenite) Fe phases are observed in the XRD profile, with the relative amounts being heavily dependent on both the specific temperature and exposure time at temperature. However, upon cooling to room temperature, XRD results show that only the expected BCC single ferrite phase was retained in the samples as the matrix phase.

\subsection{Mechanical Testing}

The quasi-static compression experiments were performed using an ISO certified Instron load frame, equipped with a $200 \mathrm{kN}$ load cell, and an ATS clam shell furnace. The push rods of the load frame were constructed from precision machined $\mathrm{ZrO}_{2}$ rods to minimize heat losses. The platens utilized in the studies were made from machined WC, which is good to $800{ }^{\circ} \mathrm{C}$ before it oxidizes [50]. These platens were precision machined within $2.5 \mu \mathrm{m}$ in all dimensions. The interfaces between the platens and samples were carefully lubricated to mitigate any friction effects using $B N$, which maintains its lubricative properties up to $900^{\circ} \mathrm{C}$ [51]. Samples were held at temperature for $10 \mathrm{~min}$ prior to loading at displacement of $0.1524 \mathrm{~mm} \mathrm{~min}^{-1}$. Tests were conducted at $24{ }^{\circ} \mathrm{C}$ 
(RT), $400^{\circ} \mathrm{C}, 500^{\circ} \mathrm{C}$, and $600^{\circ} \mathrm{C}$ for each ECAE consolidation temperature. Samples were tested inside the furnace under ambient atmospheric conditions. Digital image correlation (DIC) was utilized for RT testing to determine the true specimen strain. Vickers microhardness tests were performed using a Tukon 1202 with a Vickers diamond indenter using $50 \mathrm{~g}$ load and a dwell time of $10 \mathrm{~s}$. The reported hardness data is an average, calculated by taking at least 7 individual indents on each sample with the respective errors bars being the standard deviation.

Some of the mechanical test temperatures (up to $600{ }^{\circ} \mathrm{C}$ ) enter into a regime on the equilibrium phase diagram where both BCC ferrite and FCC austenite exist in a twophase region for the Fe-Ni-Zr system. For instance, in the binary Fe-Ni phase diagram, this two phase region should start to occur at temperatures above $347^{\circ} \mathrm{C}$. High temperature $\mathrm{XRD}$ was performed at the various test temperatures to examine the phases present. These results revealed that the matrix consists of only the BCC ferrite, contrary to the expected equilibrium two-phase region predicted by the binary phase diagram of Fe-Ni. However, the kinetics of the ferrite to austenite transformation at temperatures below $800{ }^{\circ} \mathrm{C}$ often involve a very sluggish diffusion process, with rates requiring very long times to establish an equilibrium state [52]. Therefore, while the austenite phase was not observed during the limited exposure time at these test temperatures, it is possible that this phase transformation occurs during extended times at temperatures.

\subsection{Microstructural Characterization}

APT studies were conducted using a Cameca Local Electrode Atom Probe 
(LEAP®) 3000XSi system. The APT tip blanks ( 1 $\mu \mathrm{m}$ diameter) were prepared using a FEI Quanta 200 3D Dual Beam ${ }^{\mathrm{TM}}$ focus ion beam microscope with a Ga beam followed by annular milling for final sharpening at $30 \mathrm{keV}$ beam energy with beam currents ranging from $0.3 \mathrm{nA}$ to $0.5 \mathrm{nA}$. The low energy clean-up was performed at $5 \mathrm{keV}$ with 50 pA beam current. The APT studies were conducted in laser mode with a pulse repetition rate of $250 \mathrm{kHz}$, a pulse energy of $0.4 \mathrm{~nJ}$, and a base temperature of $40 \mathrm{~K}$. The APT datasets were reconstructed using the Image Visualization and Analysis Software $\left(\right.$ IVAS $\left.^{\mathrm{TM}}\right)$, version 3.6.6 package. Evaporation artifacts due to trajectory aberrations can result in an artificial increase of the matrix ions near the precipitate/matrix interface and affect the composition analysis [53]. However, this artifact is dominant in precipitates that are smaller than $2 \mathrm{~nm}$ in diameter and can be alleviated when the composition is extracted from the plateau in composition near the core of the precipitate [53]. The precipitates in our study are larger than $5 \mathrm{~nm}$ in diameter and their composition is extracted from the plateau regions. The error of the composition is calculated based on counting statistics.

The same type of system, used for preparing the atom probe tips, was also used for preparing cross-sections for ion-channeling contrast imaging and transmission electron microscope (TEM) samples. All TEM analysis was performed using a JEOL $2100 \mathrm{~F}$ (scanning) transmission electron microscope ((S)TEM). The STEM bright-field image was taken at a camera length of $150 \mathrm{~cm}$ using the JEOL bright field detector.

\section{Results and Discussion}




\subsection{Effect of Consolidation Temperature on Microstructure}

Figures 1 (a-d) show the effect of consolidation temperature on the grain structure of Fe-Ni-Zr samples bulk consolidated at $700{ }^{\circ} \mathrm{C}, 800{ }^{\circ} \mathrm{C}, 900{ }^{\circ} \mathrm{C}$, and $1000{ }^{\circ} \mathrm{C}$, respectively. The ion channeling effect from the focused ion beam channeling contrast imaging $(\mathrm{FIBCCl})[54]$ accentuates the contrast between different crystal orientations, which allows for an immediate comparison of the grain structure evolution. There are three results of note here. First, as the ECAE (consolidation) temperature increases from $700{ }^{\circ} \mathrm{C}$ to $1000{ }^{\circ} \mathrm{C}$, Figs. 1 (a-d), the grain size increases from being submicrometer (i.e., nanocrystalline/ultrafine-grained) to $\sim 5 \mu \mathrm{m}$ grains. Second, a large number of sub-micrometer diameter precipitates (circled in red) are resolvable in samples consolidated at $900^{\circ} \mathrm{C}$ and $1000{ }^{\circ} \mathrm{C}$, see Figs. 1 (c) and (d) (please also see high resolution images provided online). Third, the grain boundary regions of the samples consolidated at $900{ }^{\circ} \mathrm{C}$ and $1000{ }^{\circ} \mathrm{C}$, Figs. 1 (c) and (d), take on a jagged appearance. This irregular phase boundary arrangement is most likely due to extensive grain boundary-particle interactions (Zener pinning). From the collection of micrographs, it is observed that the two most extreme grain structures are from samples consolidated at $700{ }^{\circ} \mathrm{C}$ and $1000{ }^{\circ} \mathrm{C}$ (Figs. 1(a) and (d)). As such, the remainder of this discourse focuses on the samples consolidated at $700{ }^{\circ} \mathrm{C}$ and $1000^{\circ} \mathrm{C}$ only.

Figures 2(a) and (b) are transmission electron microscope (TEM) bright field images of the two limiting conditions, $700{ }^{\circ} \mathrm{C}$ and $1000{ }^{\circ} \mathrm{C}$. The grain size in the samples consolidated at $700{ }^{\circ} \mathrm{C}$ is $\sim 100 \mathrm{~nm}$, which is consistent with the ion contrast channeling images showing a sub-micrometer grain structure. The samples consolidated at 1000 ${ }^{\circ} \mathrm{C}$ show a coarsened grain size of $\sim 5 \mu \mathrm{m}$. In addition, the $1000{ }^{\circ} \mathrm{C}$ condition has an 
increased presence of coarser, secondary particles, whereas the $700{ }^{\circ} \mathrm{C}$ condition was found to have a significantly lower density. To more clearly distinguish these larger secondary particles in the samples consolidated at $1000{ }^{\circ} \mathrm{C}$, a dark field image, Fig. 2(c), was captured to illustrate both the number of particles and their size. Ideally, a corresponding dark field image would be taken from the samples consolidated at 700 ${ }^{\circ} \mathrm{C}$; however, due to a lack of the large scale particles, few very faint reflections were observed in the selected area diffraction pattern for this condition. Additional discussion on the chemistry of the observed particles is provided in Section 3.2.

\subsection{Quasistatic Compression Testing}

The RT compression properties for the ECAE consolidated Fe-Ni-Zr samples processed at $700{ }^{\circ} \mathrm{C}$ and $1000^{\circ} \mathrm{C}$ were measured, and the results are shown in Figure 3. There are three main points to note. First, the different microstructural features (average grain size, precipitate size, and density (Figs. 1(a) and 1(d))) result in a strong contrast in mechanical properties as well. The RT yield stress of samples consolidated at $700{ }^{\circ} \mathrm{C}$ is $\sim 2400 \mathrm{MPa}$, which decreases by approximately $1200 \mathrm{MPa}$ to a value of $1200 \mathrm{MPa}$ for samples consolidated at $1000{ }^{\circ} \mathrm{C}$. Clearly, the $700{ }^{\circ} \mathrm{C}$ sample (smaller grain size) is strengthened via the Hall-Petch mechanism more so than that of the $1000{ }^{\circ} \mathrm{C}$ condition. However, the Hall-Petch mechanism alone cannot account for this increase in yield stress, which lends credence to the role that secondary particles play versus the coarsened version in the $1000{ }^{\circ} \mathrm{C}$ microstructure [55]. Second, both the strain to failure and the strain hardening increase significantly with the increasing ECAE processing temperature from $700{ }^{\circ} \mathrm{C}$ to $1000{ }^{\circ} \mathrm{C}$. These increases result in substantial ductility in the $1000^{\circ} \mathrm{C}$ condition corresponding to the larger grain size and, conversely, 
the loss of ductility but higher strength for the finer grained $700{ }^{\circ} \mathrm{C}$ condition. Third, the local color-contour strain maps from DIC measurements, in the compression direction during testing, (Figs. 3(b) and 3(c)) shed light on the different deformation behavior of the sets of samples consolidated at $700{ }^{\circ} \mathrm{C}$ and $1000{ }^{\circ} \mathrm{C}$, respectively (see Fig. 3(a), black and red curves, respectively). For the sample consolidated at $700{ }^{\circ} \mathrm{C}$ (Fig. 3(b)) the majority of the strain is localized within a narrow shear band oriented almost $45^{\circ}$ to the parallel impact faces of the sample, demonstrating a shear instability; note, these samples fracture prior to reaching $4 \%$ strain.

Much like that observed in other bcc metals [56-57], the decreased grain size (and corresponding higher strength) in the Fe-Ni-Zr samples alters the balance between hardening and softening mechanisms. As the work hardening capacity of the material is exhausted, thermal softening ensues, and the material weakens along the plane of maximum shear. Under such geometric softening conditions [57], a shear instability could develop even under quasi-static loading; in our case, such shear banding is likely enhanced by localized rotation and alignment of ultrafine grains, in a direction which supports easy slip and glide. However, this behavior was absent as demonstrated in Fig. 3(c) for the samples with much larger grain sizes. In these samples, a more stable deformation conditions existed, resulting in plastic flow up to strains of $30 \%$ without failure or microcracking.

\subsection{Nanoscale Characterization - TEM and Atom Probe Tomography}

Atom probe tomography was then performed on samples consolidated at $700{ }^{\circ} \mathrm{C}$ and $1000{ }^{\circ} \mathrm{C}$ to further understand the differences in the dispersed oxide network at the nanoscale. The top and bottom panels of Fig. 4 show the APT reconstructions of the 
Fe-Ni-Zr alloy, consolidated at $700{ }^{\circ} \mathrm{C}$ and $1000^{\circ} \mathrm{C}$, respectively. Figure 4 shows atom maps of different elements to highlight the presence of (a) larger $\mathrm{Zr}$-containing phase and (b) an oxide-based phase that is consistent with the observation made in Section 3.1. The primary result is that for both consolidation temperatures, two distinct types of $\mathrm{Zr}$-containing phases form in the alloy: (a) a larger $\mathrm{Zr}$-containing phase, approximately $40-50 \mathrm{~nm}$ in size and (b) a smaller oxide-based precipitates, less than 5 $\mathrm{nm}$ in radius. As the smaller oxide-based phase is believed to be responsible for the mechanical properties of these alloys, it is delineated using an isoconcentration surface (8 at.\% ZrO), shown in Fig. 4 (c) to illustrate its size and distribution. The following sections discuss nanoscale characterization of both these phases.

\subsubsection{Larger Zr Containing Phases $\sim 40-50 \mathrm{~nm}$ in size}

The larger Zr-containing phases are observed at both processing temperatures. The size of these phases, their distribution as observed in TEM, and the limited field of view in an APT specimen made it challenging within the scope of this study to capture a significant number for proper analysis, however, some observations were made. Fig. $5(a)$ is a scanning transmission electron microscope, (S)TEM, bright field image of the sample consolidated at $1000{ }^{\circ} \mathrm{C}$ and shows non-uniform distribution of these larger precipitates. Generally, it is observed that these larger precipitates are primarily composed of $\mathrm{Fe}, \mathrm{Ni}$, and $\mathrm{Zr}$ with some level of oxygen and trace elements (e.g., $\mathrm{N}$ and $\mathrm{Cr}$ ), presumably contamination from the milling media during processing. The $\mathrm{Zr}$ composition is elevated in this phase, approximately an order of magnitude higher than the $\mathrm{Zr}$ content in the surrounding matrix generally. The level of oxygen and other trace elements increased within these particles at the higher consolidation temperature of 
$1000^{\circ} \mathrm{C}$. The chemical analysis attained from APT is consistent with energy dispersive $\mathrm{x}$-ray spectroscopy (EDS) measurements performed within the TEM as seen in Fig. 5 with the elemental maps of (b) $\mathrm{Fe}$, (c) $\mathrm{O}$, (d) $\mathrm{Ni}$, and (e) $\mathrm{Zr}$ represented by red, blue, green, and cyan respectively. However, more extensive studies that were outside the scope of the present work are needed to provide a clear picture of these phases. The role that these precipitates play in mechanical properties is further discussed in Section 3.3.3.

\subsubsection{Smaller Oxide-Based Precipitates ( $<5 \mathrm{~nm}$ in Radius)}

The volume-equivalent radius (VER) of the oxide-based precipitates, Fig. 4(c), increases from $2.34 \mathrm{~nm} \pm 0.63 \mathrm{~nm}$ to $3.98 \mathrm{~nm} \pm 1.18 \mathrm{~nm}$ (a 70\% VER increase) as the consolidation temperature increases from $700^{\circ} \mathrm{C}$ to $1000^{\circ} \mathrm{C}$. The aforementioned error for the VER calculations is the standard deviation of the distribution. As the oxidebased precipitate size increases with increasing ECAE consolidation temperature (from $700^{\circ} \mathrm{C}$ to $1000^{\circ} \mathrm{C}$ ), the corresponding number density of the oxide-based precipitates

decreases from $(13.36 \pm 1.38) \times 10^{22} \mathrm{~m}^{-3}$ to $(3.51 \pm 0.84) \times 10^{22} \mathrm{~m}^{-3}$ (a 74\% decrease) respectively. The error for the number density is based on counting statistics. The change in size and number density of oxide precipitates with consolidation temperature is related to the dependence of solubility and diffusivity on temperature.

\subsubsection{Chemistry of the Smaller Oxide-Based Precipitates}

Generally, it has been accepted in ODS alloys that the presence of smaller oxide phases (with diameters less than $8 \mathrm{~nm}$ ) are responsible for the elevated mechanical 
properties. Since it is expected that the smaller oxide-based precipitates are primarily responsible for the high yield strength of the Fe-Ni-Zr alloys reported here, detailed composition analysis of these precipitates was performed using a proximity histogram or a proxigram [58]. A proxigram is a three-dimensional (3D) average composition profile as a function of distance from the precipitate/matrix interface (in this case, the 8 at.\% $\mathrm{ZrO}$ isoconcentration surface) integrated over selected precipitates. Fig. 6 shows a representative oxide precipitate (top) with its corresponding proxigram (bottom) of the alloy consolidated at (a) $700{ }^{\circ} \mathrm{C}$ and (b) $1000{ }^{\circ} \mathrm{C}$. The main result is that the amount of $\mathrm{ZrO}$ in the precipitates increases from $36.37 \pm 0.91$ to about $78.92 \pm 0.90$ (at.\%) as the consolidation temperature is increased from $700^{\circ} \mathrm{C}$ to $1000^{\circ} \mathrm{C}$. The main constituent in the precipitates is $\mathrm{ZrO}$ and, therefore, the proxigram shows only the $\mathrm{ZrO}$ concentration. At $700{ }^{\circ} \mathrm{C}$, these precipitates also have less than 10 at. $\%$ of $\mathrm{Fe}$ - and Ni-based oxides and oxygen. The composition of the matrix obtained approximately $3.5 \mathrm{~nm}$ from the precipitate/matrix interface is $83.19 \pm 0.03 \mathrm{Fe}, 11.07 \pm 0.03 \mathrm{Ni}, 3.27 \pm 0.02 \mathrm{Zr}, 1.13 \pm$ $0.01 \mathrm{ZrO}$ and $0.09 \mathrm{O}$ (at.\%). The matrix composition indicates two results: 1) after processing, all $\mathrm{Zr}$ has not been converted to $\mathrm{ZrO}$, and 2) most of the $\mathrm{ZrO}$ has formed precipitates, leaving very little elemental oxygen in the matrix. These results suggest that by controlling the amount of oxygen, the precipitation behavior can be tailored to obtain the desired mechanical properties.

At $1000{ }^{\circ} \mathrm{C}$, the oxide-based precipitates have $78.92 \pm 0.90 \mathrm{ZrO}, 10.89 \pm 0.67 \mathrm{O}$, and less than 5 of $\mathrm{Fe}$ - and $\mathrm{Ni}$-based oxides (at.\%). The oxygen is in the core of the precipitates. It is not known whether this oxygen is a part of the oxides and evaporated as an oxygen ion or whether this oxygen is elemental oxygen. The composition of the 
matrix obtained from approximately $3.5 \mathrm{~nm}$ from the precipitate/matrix interface is 90.76 $\pm 0.05 \mathrm{Fe}, 6.70 \pm 0.04 \mathrm{Ni}, 1.27 \pm 0.02 \mathrm{ZrO}$ and less than $0.4 \%$ elemental oxygen and Fe- and Ni-based oxides (at.\%).

\subsection{Temperature Dependence of Yield Strength}

Fig. 7 plots the compressive yield properties of the ODS Fe-Ni-Zr alloys as a function of processing and testing temperature. The samples consolidated at $700{ }^{\circ} \mathrm{C}$, $800{ }^{\circ} \mathrm{C}$, and $1000^{\circ} \mathrm{C}$ were each tested at $\mathrm{RT}, 400^{\circ} \mathrm{C}$, and $600^{\circ} \mathrm{C}$ and reveal several interesting observations. First, the RT compressive yield strength is a function of the ECAE consolidation temperature and is $2400 \mathrm{MPa}, 1600 \mathrm{MPa}$, and $1200 \mathrm{MPa}$ for consolidation temperatures $700{ }^{\circ} \mathrm{C}, 800^{\circ} \mathrm{C}$, and $1000^{\circ} \mathrm{C}$, respectively. Specifically, the Fe-Ni-Zr alloy processed at $700{ }^{\circ} \mathrm{C}$ exhibits a very high yield stress of $2400 \mathrm{MPa}$ at $\mathrm{RT}$, indicating a dramatic twofold increase in yield strength with a concurrent decrease in the ECAE processing temperature from $1000^{\circ} \mathrm{C}$ to $700^{\circ} \mathrm{C}$. This increased strength can be explained by noting that over the same temperature range, the particle size distribution of the oxide-based precipitates shifts to a smaller size (from $8 \mathrm{~nm}$ to $4 \mathrm{~nm}$ ) and the corresponding number density increases by a factor of 3.8 (see Fig. 8). Recall that a much smaller grain size (approximately $100 \mathrm{~nm}$ ) is also retained in the sample processed at $700{ }^{\circ} \mathrm{C}$, but the complete increase in strength (expected to be approximately $1.5 \mathrm{GPa}$ for an average grain size of $100 \mathrm{~nm}$ in pure $\mathrm{Fe}$ ) cannot be explained by grain size strengthening alone $[55,59]$. The rapid coarsening and loss of strength after processing at $1000^{\circ} \mathrm{C}$ is likely related to a reduced Zener pinning effect due to particle coarsening as well as abnormal grain growth induced by the bcc-to-fcc phase transformation $[59,60,61]$. Second, such strength properties $(1200-2400 \mathrm{MPa})$ 
are in line with historically used 52100, 440C, and the more modern REX20 and CRU80 high strength and wear resistant steels (1360-3445 MPa) used in advanced bearing applications [62]. In fact, the hardness values of the as-milled Fe-Ni-Zr powder (approximately $11 \mathrm{GPa}$ ) suggest peak compressive yield stress values which compare well against high hardness REX20 also produced via powder metallurgy processes [62]. Third, all alloys display significant strength losses above $500^{\circ} \mathrm{C}$. That is, the observed yield strengths reduced rapidly above $500^{\circ} \mathrm{C}$ and converge to $600-800 \mathrm{MPa}$ at about $600^{\circ} \mathrm{C}$ for all alloys. In general, all of the alloys converge to approximately the same strength value, but their respective rates of decrease differ, indicating varying degrees of thermal softening depending on the consolidation temperature.

The high temperature mechanical testing may alter the grain structure and/or precipitates, which in turn reduces the strength. Therefore, Vickers microhardness tests were performed at RT to assess whether the decrease in properties is due to a changing microstructure at high temperatures or is due to a thermal softening effect, which could include increased atomic and dislocation mobility, the activation of slipsystems, or reduced elastic moduli changes in the overall deformation mechanisms [63]. To delineate these two effects, additional hardness tests were conducted on samples after isothermally annealing them at the compression testing temperatures, i.e., $400{ }^{\circ} \mathrm{C}, 500^{\circ} \mathrm{C}$, and $600^{\circ} \mathrm{C}$, for 1 hour and then testing them at RT. The tests at RT naturally preclude the effect of thermal softening and thus elucidate softening related to microstructural changes. Tabor's Rule [64] (relating Vickers microhardness to yield strength) was then used to estimate the yield strength of these samples. These results (Fig. 7) show that direct exposure to the compression testing temperatures did 
not significantly alter the as-ECAE-processed microstructure (and mechanical properties). That is, the large majority of the observed decrease in properties can be attributed to thermal softening, and is thus not strongly related to microstructural softening effects such as grain growth, particle coarsening, or loss of solid solution strengthening. Interestingly, this observation also indicates that smaller grain sizes and particles (present at $700^{\circ} \mathrm{C}$ ) are more sensitive to thermal softening than larger grains and larger particles (present at $1000^{\circ} \mathrm{C}$ ). For instance, the samples consolidated at $700{ }^{\circ} \mathrm{C}$ underwent a reduction in yield strength of $75 \%$ (from RT to $600{ }^{\circ} \mathrm{C}$ ), while samples consolidated at $800{ }^{\circ} \mathrm{C}$ and $1000{ }^{\circ} \mathrm{C}$ underwent $64 \%$ and $48 \%$ reduction only, respectively. Therefore, there may be a limit to the ability to increase and retain strength at high temperatures, wherein smaller precipitates and grain sizes help to increase strength at low temperatures, but are more easily bypassed at higher temperatures. Depending on the elevated temperature of interest, there may likely exists a crossover point, at which engineering a larger high strength phase becomes a better rationale for achieving higher strengths than relying on the dispersion of smaller precipitates or phases.

\section{Conclusions}

In this work, a series of bulk alloys containing $\mathrm{Zr}$ were created to assess the viability of engineering oxide-dispersed-strengthened $\mathrm{Fe}$ based alloys with $\mathrm{Zr}$ that operate at moderate to high temperatures. High energy mechanical alloying in combination with high temperature ECAE resulted in a bulk consolidated Fe-based ODS alloy. Bulk consolidation at various elevated temperatures resulted in different sample 
microstructures, with a range of grain sizes and precipitate sizes. Consolidating the alloy at $700^{\circ} \mathrm{C}$ resulted in nano/ultrafine grains and large $(50 \mathrm{~nm})$ intermetallic precipitates and small (less than $5 \mathrm{~nm}$ diameter) $\mathrm{Zr}$ oxide clusters, whereas consolidation at $1000{ }^{\circ} \mathrm{C}$ resulted in micrometer-sized grains and large $(50 \mathrm{~nm})$ intermetallic precipitates and small (less than $10 \mathrm{~nm}$ diameter) $\mathrm{Zr}$ oxide clusters. In all cases, the presence of the precipitates and clusters were confirmed by APT.

The observed mechanical properties were also a strong function of the consolidation temperature and, as such, could be attributed to the difference in grain size, precipitate size, and number density prevailing at those consolidation conditions. Room temperature quasi-static compression testing of the two most extreme or different microstructures (as functions of grain size and precipitate size) results in a correspondingly wide range of properties, with samples possessing yield strengths between $1200 \mathrm{MPa}$ and $2400 \mathrm{MPa}$. Increasing the consolidation temperature from $700{ }^{\circ} \mathrm{C}$ to $1000{ }^{\circ} \mathrm{C}$ also resulted in a large improvement in ductility. Samples having micrometer-sized grains (greater than $1000 \mathrm{~nm}$ ) exhibited strains of $\sim 30 \%$ at RT, showing no signs of failure.

Last, smaller grain sizes and particles appear to be more sensitive to thermal softening than larger grains and larger particles. Therefore, achieving and retaining high strengths above $600^{\circ} \mathrm{C}$ likely requires maximizing the tradeoffs between such microstructural features. Further tradeoffs between strength and ductility may be engineered by manipulating both the alloy composition (especially the Zr content) and processing, thereby engineering the grain size, cluster dispersion and size, and their number density for this class of alloys. 


\section{Acknowledgments}

M. Kapoor and G.B. Thompson gratefully acknowledge support from Sandia National Laboratories through the Department of Energy Office of Basic Energy Sciences. 


\section{Figures}
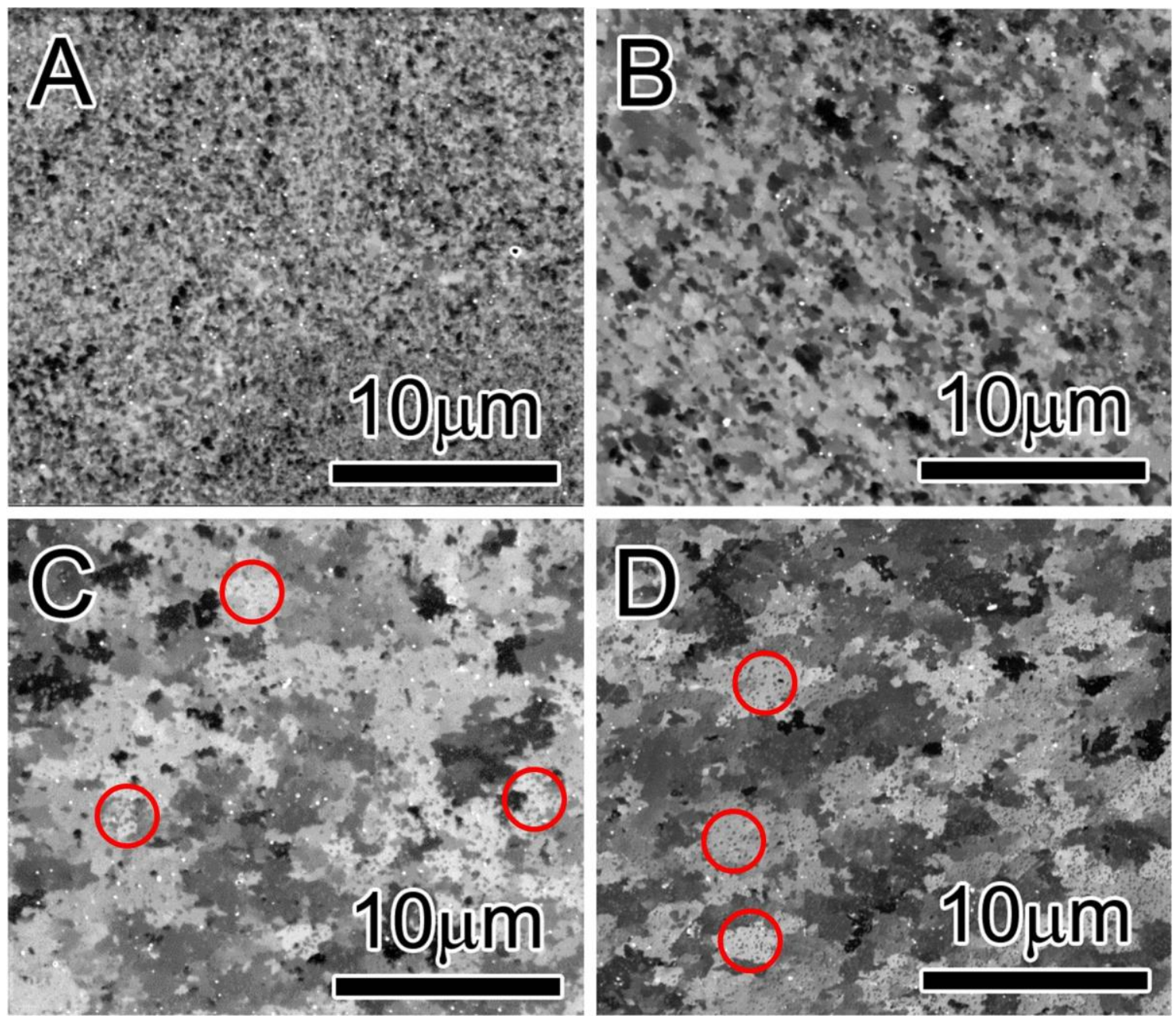

Figure 1. 


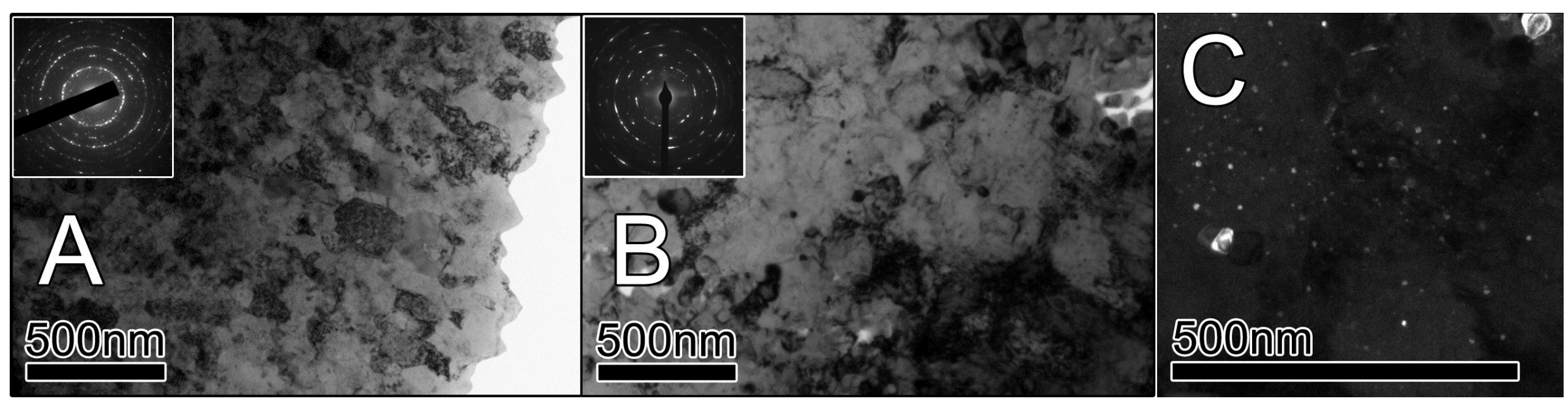

Figure 2. 

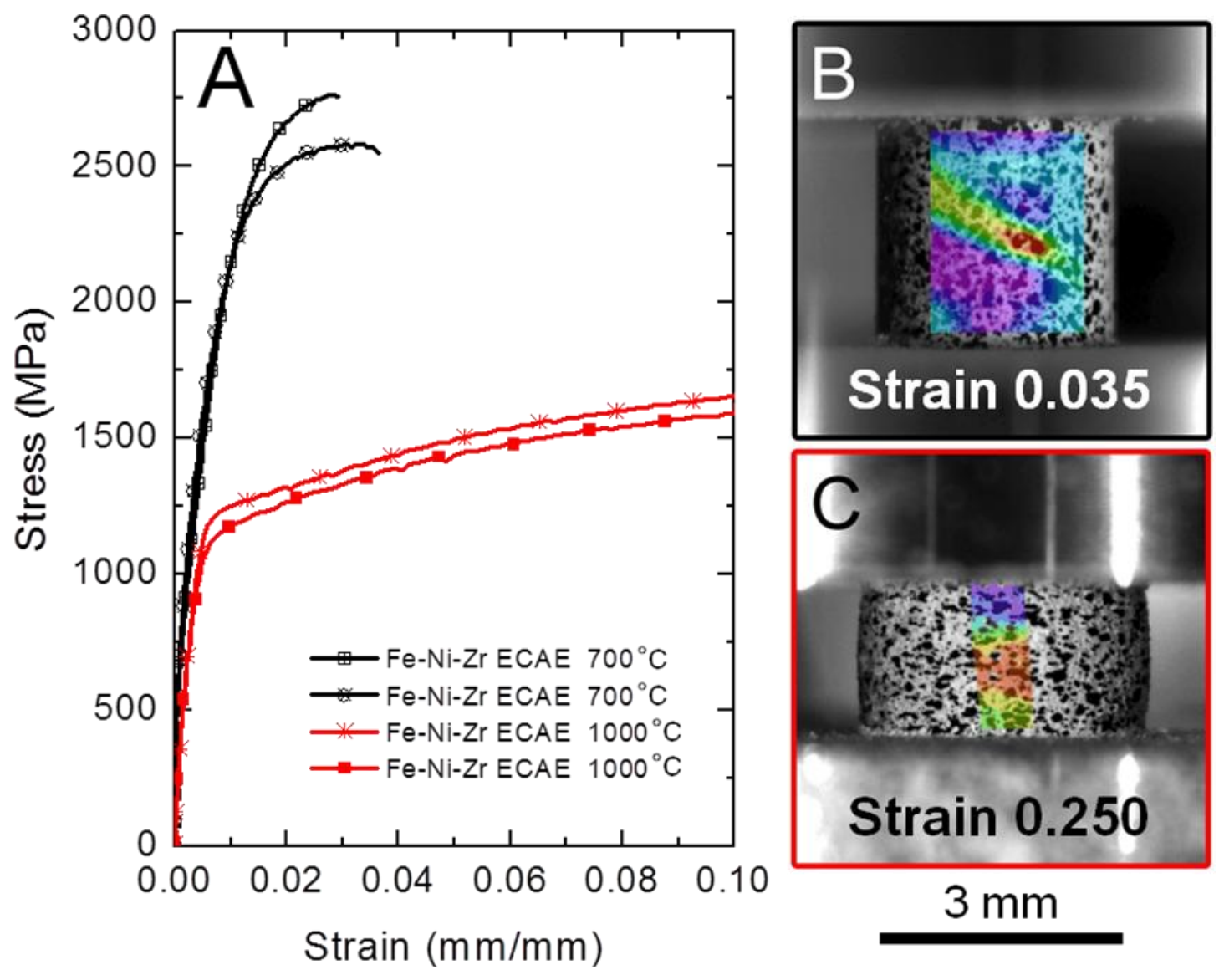

Figure 3. 

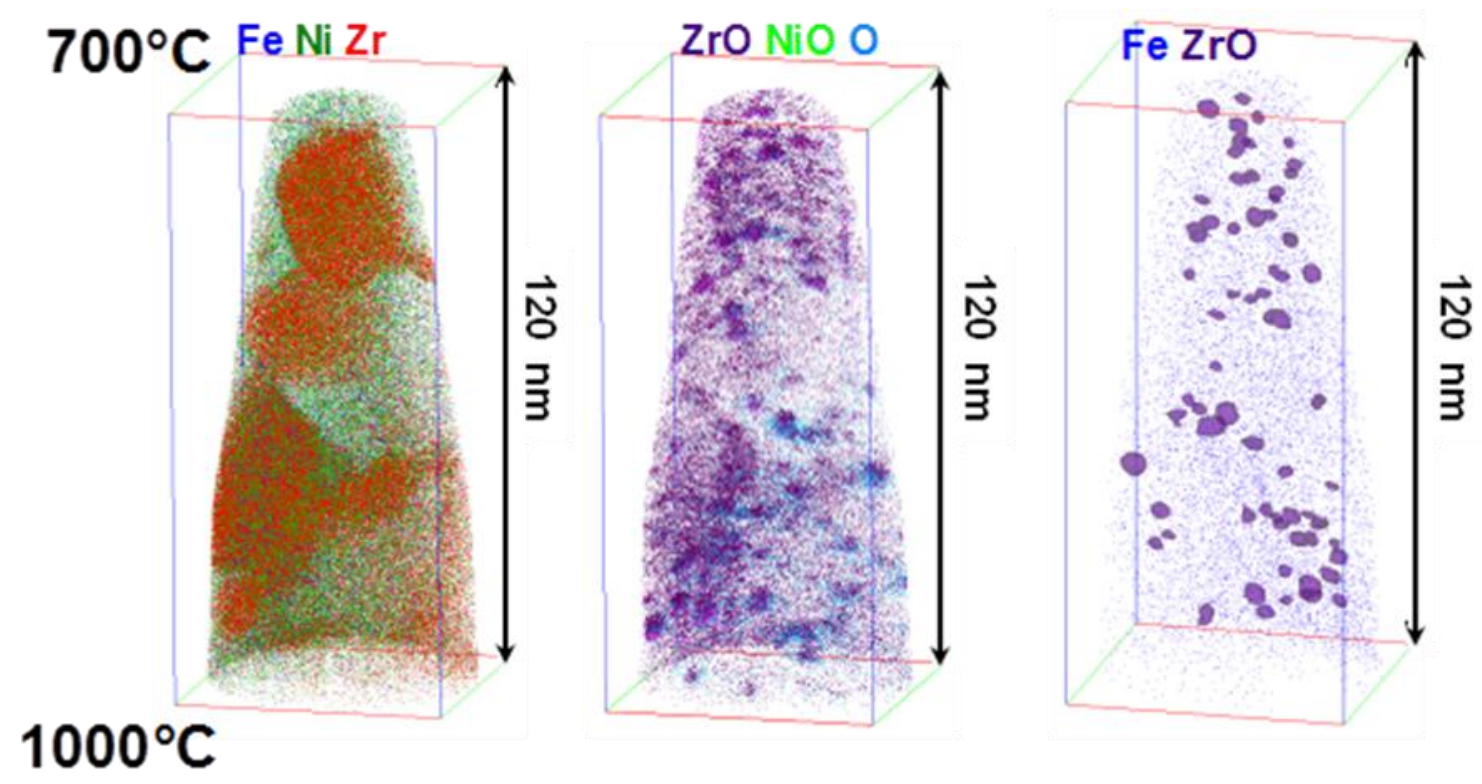

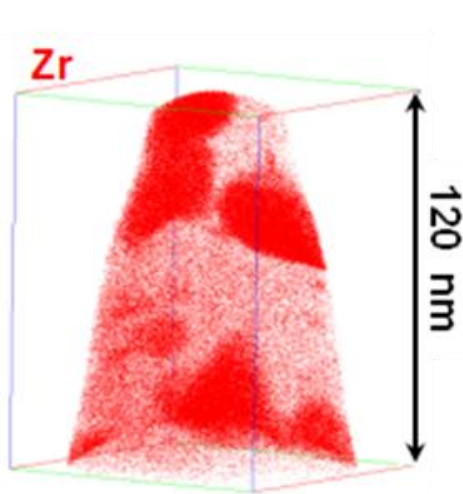

(a)

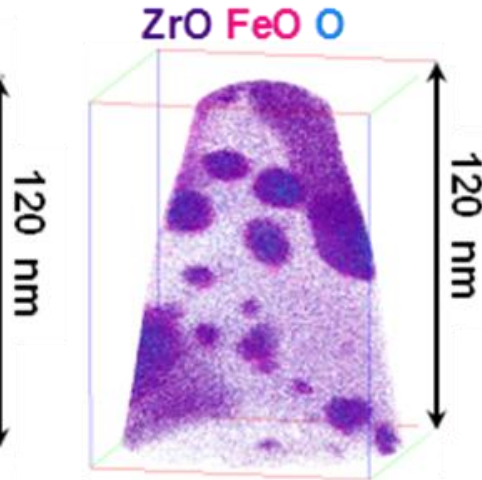

(b)

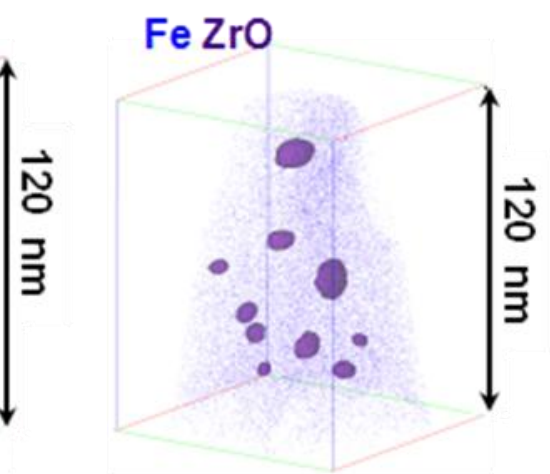

(c)

Figure 4 . 


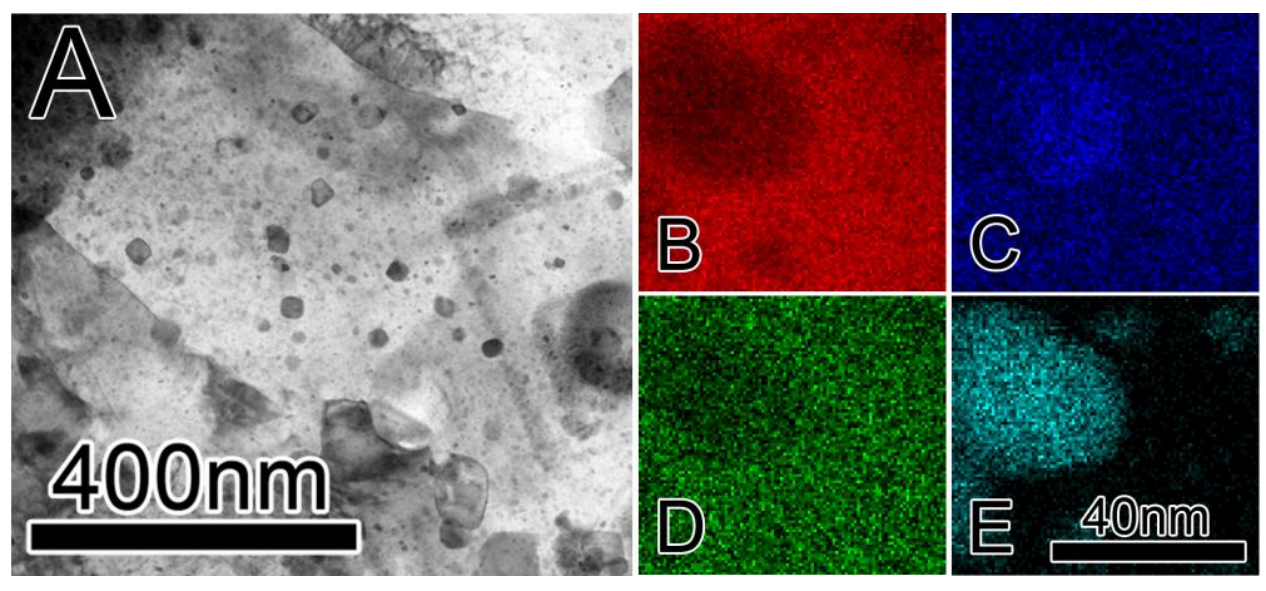

Figure 5. 

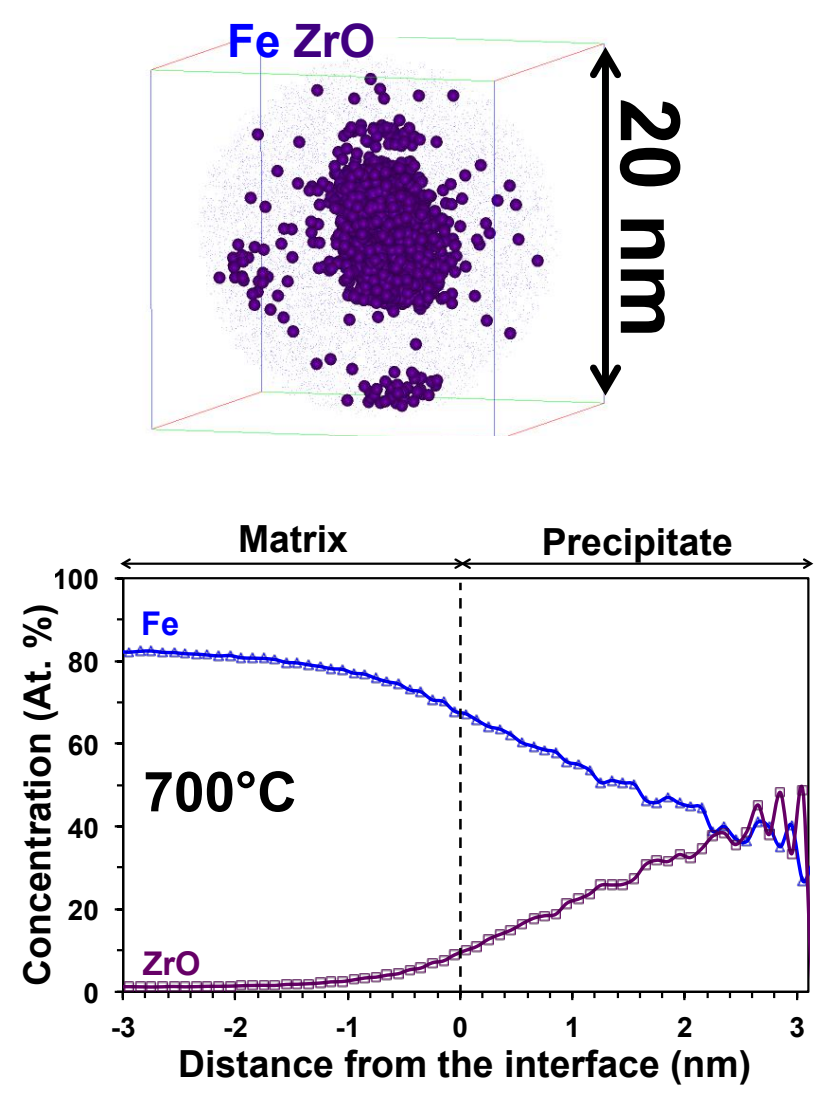
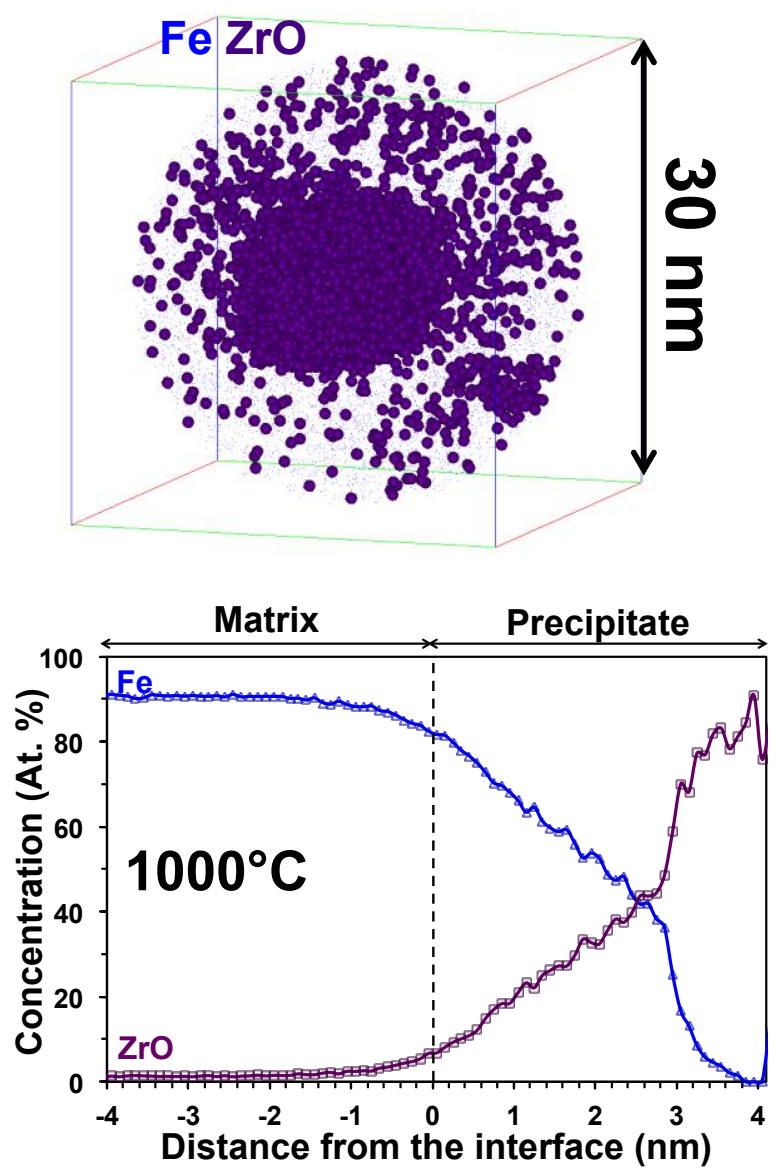

Figure 6. 


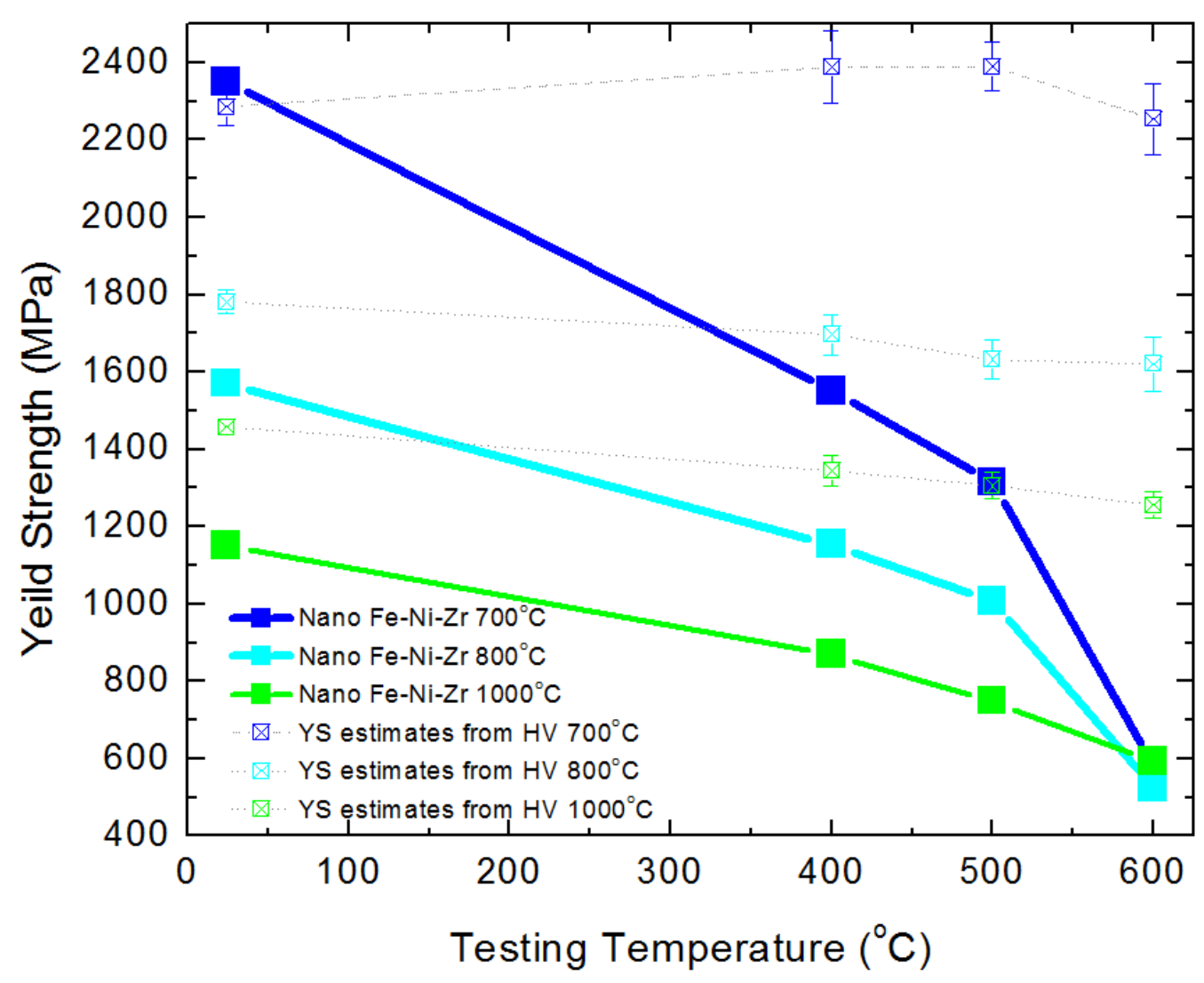

Figure 7. 


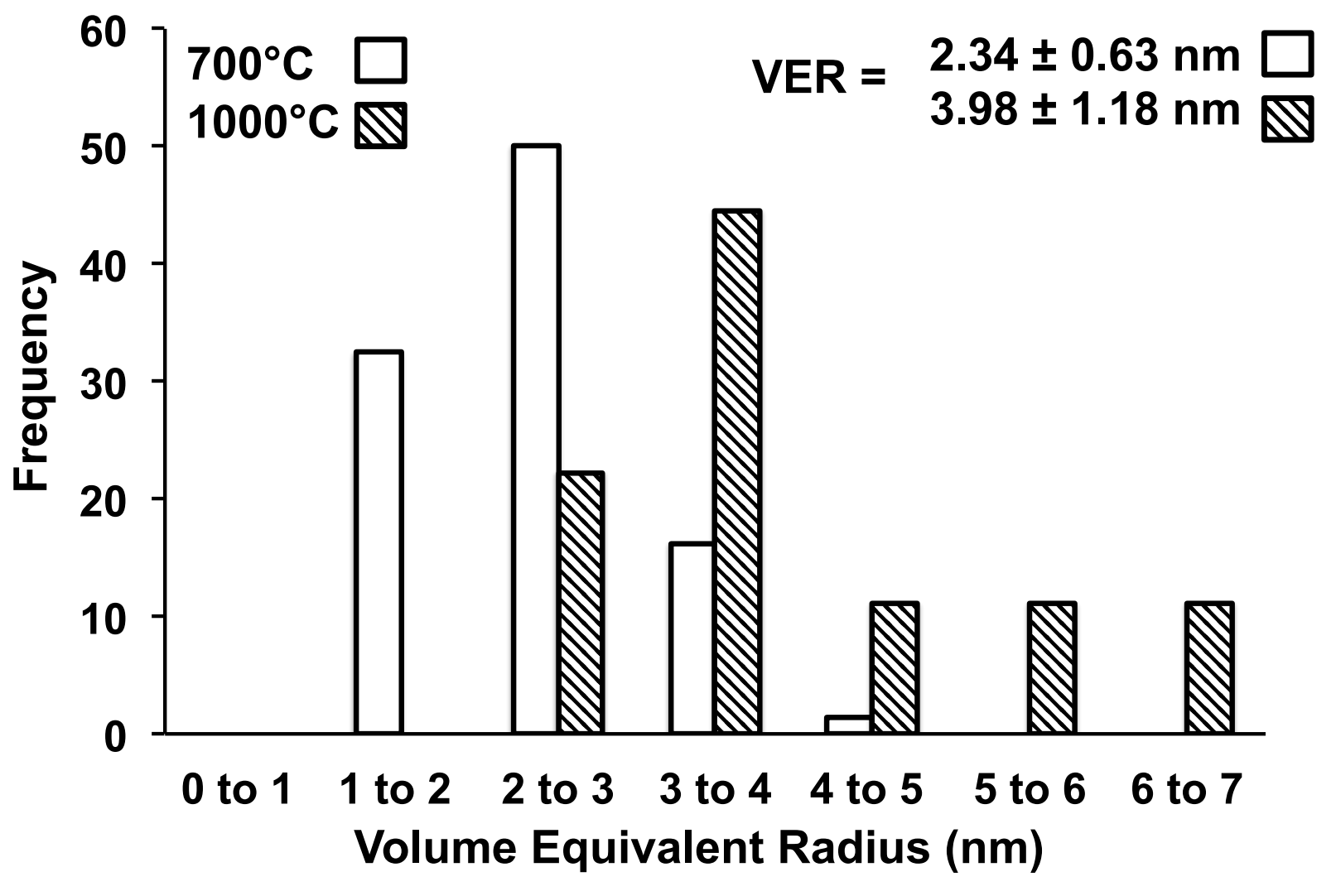

Figure 8. 


\section{Figure Captions}

Figure 1. Focused ion beam channeling contrast image produced from a representative cross section of each of the ECAE consolidated samples at (a) $700^{\circ} \mathrm{C}$, (b) $800^{\circ} \mathrm{C}$, (c) $900^{\circ} \mathrm{C}$, and (d) $1000^{\circ} \mathrm{C}$. The ion channeling contrast effect highlights crystal orientation contrast and shows the coarsening of the grain structure at higher ECAE processing temperatures.

Figure 2. Bright-field image of the samples ECAE consolidated at (a) $700{ }^{\circ} \mathrm{C}$ and (b) $1000{ }^{\circ} \mathrm{C}$ with their respective selected area electron diffraction patterns inset in the upper left hand corners. Note the clear increase in grain size and coarsened, secondary particles present with increasing ECAE temperature. (c) Dark-field image of the ECAE consolidated sample at $1000{ }^{\circ} \mathrm{C}$ differentiating the secondary particles from the matrix providing insight on their size and frequency.

Figure 3. (a) Quasi-static compression results from samples that were ECAE consolidated at $700^{\circ} \mathrm{C}$ (black) and $1000^{\circ} \mathrm{C}$ (red). (b and c) Images of the compressed, speckle-patterned samples with an overlaid DIC strain map in the compressive direction is shown for samples ECAE processed at (b) $700{ }^{\circ} \mathrm{C}$ and (c) $1000^{\circ} \mathrm{C}$. The $700{ }^{\circ} \mathrm{C}$ consolidated samples have higher yield/ultimate strengths with a concentrated strain gradient (shear banding), while the $1000{ }^{\circ} \mathrm{C}$ consolidated samples have lower strengths and higher strains to failure due to a more uniform distribution of strain. 
Figure 4. 3D Atom probe tomography reconstruction of $\mathrm{Fe}-\mathrm{Ni}-\mathrm{Zr}$ alloys consolidated at $700{ }^{\circ} \mathrm{C}$ and $1000^{\circ} \mathrm{C}$, respectively, showing atom maps (for a fraction of the atoms) of (a) the larger $\mathrm{Zr}$-containing second phase, (b) the smaller oxide precipitates, as well as (c) an isoconcentration surface ( 8 at.\% ZrO) of the small oxide precipitates. Only some elements are shown for clarity.

Figure 5: (a) (S)TEM bright-field image of the samples ECAE consolidated at $1000^{\circ} \mathrm{C}$. Note the non-uniform distribution of the coarser precipitates. Elemental maps taken from a region containing one of the coarser precipitates representing the individual elements (b) $\mathrm{Fe},(\mathrm{c}) \mathrm{O},(\mathrm{d}) \mathrm{Ni}$, and (e) $\mathrm{Zr}$ respectively.

Figure 6: 3D atom probe tomography reconstructions of a representative oxide precipitate and the corresponding proxigram concentration profiles (at.\%) as a function of distance from the interface for $\mathrm{Fe}$ and $\mathrm{ZrO}$ for the oxide precipitates in alloys consolidated at (a) $700{ }^{\circ} \mathrm{C}$ and (b) $1000^{\circ} \mathrm{C}$. Only Fe and $\mathrm{ZrO}$ atoms are shown in the oxide precipitates.

Figure 7: Compression yield properties of the ODS alloys herein plotted against testing temperature. This Fe-based ODS alloy with Zr oxide precipitates shows a twofold increase in the RT strength (from $\sim 1200 \mathrm{MPa}$ to $2400 \mathrm{MPa}$ ). The change is attributed to a decrease of the ECAE consolidation temperature (and a corresponding change of the resultant microstructure). 
Figure 8: Oxide precipitate size distribution of the Fe-Ni-Zr alloys, heat treated at

$700{ }^{\circ} \mathrm{C}$ and $1000^{\circ} \mathrm{C} . \quad($ VER $=$ volume equivalent radius $)$.

\section{References}

[1] J. H. Kim and C. H. Park, "Effect of milling temperature on nanoclusters and ultra fine grained microstructure of oxide dispersion strengthened steel," Journal of Alloys and Compounds, vol. 585, pp. 69-74, Feb 5 2014.

[2] J. H. Yoon, Y. Lee, S. H. Kang, T. S. Byun, and D. T. Hoelzer, "Effects of Partial Phase Transformation on Characteristics of $9 \mathrm{Cr}$ Nanostructured Ferritic Alloy," Current Nanoscience, vol. 10, pp. 47-50, Feb 2014.

[3] D. T. Hoelzer, J. Bentley, M. A. Sokolov, M. K. Miller, G. R. Odette, and M. J. Alinger, "Influence of particle dispersions on the hightemperature strength of ferritic alloys," Journal of Nuclear Materials, vol. 367, pp. 166-172, Aug 12007.

[4] J. H. Kim, T. S. Byun, D. T. Hoelzer, S. W. Kim, and B. H. Lee, "Temperature dependence of strengthening mechanisms in the nanostructured ferritic alloy 14YWT: Part I-Mechanical and microstructural observations," Materials Science and Engineering aStructural Materials Properties Microstructure and Processing, vol. 559, pp. 101-110, Jan 12013.

[5] S. Ukai and M. Fujiwara, "Perspective of ODS alloys application in nuclear environments," Journal of Nuclear Materials, vol. 307, pp. 749757, Dec 2002.

[6] S. Ukai, S. Mizuta, M. Fujiwara, T. Okuda, and T. Kobayashi, "Development of 9Cr-ODS martensitic steel claddings for fuel pins by means of ferrite to austenite phase transformation," Journal of Nuclear Science and Technology, vol. 39, pp. 778-788, Jul 2002.

[7] H. Okada, S. Ukai, and M. Inoue, "Effects of grain morphology and texture on high temperature deformation in oxide dispersion strengthened ferritic steels," Journal of Nuclear Science and Technology, vol. 33, pp. 936-943, Dec 1996.

[8] D. A. McClintock, M. A. Sokolov, D. T. Hoelzer, and R. K. Nanstad, "Mechanical properties of irradiated ODS-EUROFER and nanocluster strengthened 14YWT," Journal of Nuclear Materials, vol. 392, pp. 353359, Jul 152009.

[9] C. M. Parish, R. M. White, J. M. LeBeau, and M. K. Miller, "Response of nanostructured ferritic alloys to high-dose heavy ion irradiation," Journal of Nuclear Materials, vol. 445, pp. 251-260, Feb 2014.

[10] I. Monnet, P. Dubuisson, Y. Serruys, M. O. Ruault, O. Kaitasov, and B. Jouffrey, "Microstructural investigation of the stability under irradiation of oxide dispersion strengthened ferritic steels," Journal of Nuclear Materials, vol. 335, pp. 311-321, Dec 12004.

[11] M. K. Miller and Y. Zhang, "Fabrication and characterization of APT specimens from high dose heavy ion irradiated materials," ULtramicroscopy, vol. 111, pp. 672-675, May 2011.

[12] X. Boulnat, D. Fabregue, M. Perez, M. H. Mathon, and Y. Decarlan, "HighTemperature Tensile Properties of Nano-Oxide Dispersion Strengthened Ferritic Steels Produced by Mechanical Alloying and Spark Plasma 
Sintering," Metallurgical and Materials Transactions a-Physical Metallurgy and Materials Science, vol. 44A, pp. 2461-2465, Jun 2013.

[13] C. Suryanarayana, "Mechanical alloying and milling," Progress in Materials Science, vol. 46, pp. 1-184, 2001.

[14] C. Suryanarayana, Mechanical alloying and milling: CRC Press, 2004.

[15] G. R. Odette, M. J. Alinger, and B. D. Wirth, "Recent developments in irradiation-resistant steels," in Annual Review of Materials Research. vol. 38, ed, 2008, pp. 471-503.

[16] T. Hayashi, P. M. Sarosi, J. H. Schneibel, and M. J. Mills, "Creep response and deformation processes in nanocluster-strengthened ferritic steels," Acta Materialia, vol. 56, pp. 1407-1416, Apr 2008.

[17] A. Ramar, N. Baluc, and R. Schaublin, "On the lattice coherency of oxide particles dispersed in EUROFER97," Journal of Nuclear Materials, vol. 386-88, pp. 515-519, Apr 2009.

[18] L. Hsiung, M. Fluss, S. Tumey, J. Kuntz, B. El-Dasher, M. Wall, B. Choi, A. Kimura, F. Willaime, and Y. Serruys, "HRTEM study of oxide nanoparticles in K3-ODS ferritic steel developed for radiation tolerance," Journal of Nuclear Materials, vol. 409, pp. 72-79, Feb 2011.

[19] V. de Castro, T. Leguey, A. Munoz, M. A. Monge, P. Fernandez, A. M. Lancha, and R. Pareja, "Mechanical and microstructural behaviour of Y2030DS EUROFER 97," Journal of Nuclear Materials, vol. 367, pp. 196201, Aug 2007.

[20] M. K. Miller, K. F. Russell, and D. T. Hoelzer, "Characterization of precipitates in MA/ODS ferritic alloys," Journal of Nuclear Materials, vol. 351, pp. 261-268, Jun 2006.

[21] H. Sakasegawa, L. Chaffron, F. Legendre, L. Boulanger, T. Cozzika, M. Brocq, and $Y$. de Carlan, "Correlation between chemical composition and size of very small oxide particles in the MA957 ODS ferritic alloy," Journal of Nuclear Materials, vol. 384, pp. 115-118, Feb 2009.

[22] L. L. Hsiung, M. J. Fluss, S. J. Tumey, B. W. Choi, Y. Serruys, F. Willaime, and A. Kimura, "Formation mechanism and the role of nanoparticles in Fe-Cr ODS steels developed for radiation tolerance," Physical Review B, vol. 82, Nov 2010.

[23] X. Mao, T. K. Kim, S. S. Kim, K. H. Oh, and J. Jang, "Thermal stability of oxide particles in 12Cr ODS steel," Journal of Nuclear Materials, vol. 428, pp. 82-89, Sep 2012.

[24] P. Dou, A. Kimura, R. Kasada, T. Okuda, M. Inoue, S. Ukai, S. Ohnuki, T. Fujisawa, and F. Abe, "TEM and HRTEM study of oxide particles in an Alalloyed high-Cr oxide dispersion strengthened steel with $\mathrm{Zr}$ addition," Journal of Nuclear Materials, vol. 444, pp. 441-453, Jan 2014.

[25] M. K. Miller, D. T. Hoelzer, E. A. Kenik, and K. F. Russell, "Nanometer scale precipitation in ferritic MA/ODS alloy MA957," Journal of Nuclear Materials, vol. 329, pp. 338-341, Aug 2004.

[26] S. Yamashita, S. Ohtsuka, N. Akasaka, S. Ukai, and S. Ohnuki, "Formation of nanoscale complex oxide particles in mechanically alloyed ferritic steel," Philosophical Magazine Letters, vol. 84, pp. 525-529, Aug 2004.

[27] M. Klimiankou, R. Lindau, and A. Moslang, "Energy-filtered TEM imaging and EELS study of ODS particles and argon-filled cavities in ferriticmartensitic steels," Micron, vol. 36, pp. 1-8, 2005.

[28] H. Kishimoto, M. J. Alinger, G. R. Odette, and T. Yamamoto, "TEM examination of microstructural evolution during processing of $14 \mathrm{CrYWT} i$ nanostructured ferritic alloys," Journal of Nuclear Materials, vol. 329, pp. 369-371, Aug 2004 . 
[29] M. Klimiankou, R. Lindau, and A. Moslang, "HRTEM Study of yttrium oxide particles in ODS steels for fusion reactor application," Journal of Crystal Growth, vol. 249, pp. 381-387, Feb 2003.

[30] M. K. Miller, C. M. Parish, and Q. Li, "Advanced oxide dispersion strengthened and nanostructured ferritic alloys," Materials Science and Technology, vol. 29, pp. 1174-1178, Oct 2013.

[31] A. Hirata, T. Fujita, Y. R. Wen, J. H. Schneibel, C. T. Liu, and M. W. Chen, "Atomic structure of nanoclusters in oxide-dispersion-strengthened steels," Nature Materials, vol. 10, pp. 922-926, Dec 2011.

[32] M. C. Brandes, L. Kovarik, M. K. Miller, and M. J. Mills, "Morphology, structure, and chemistry of nanoclusters in a mechanically alloyed nanostructured ferritic steel," Journal of Materials Science, vol. 47, pp. 3913-3923, Apr 2012.

[33] M. Saber, W. Xu, L. Li, Y. Zhu, C. C. Koch, and R. 0. Scattergood, "Size effect of primary Y203 additions on the characteristics of the nanostructured ferritic ODS alloys: Comparing as-milled and asmilled/annealed alloys using S/TEM," Journal of Nuclear Materials, vol. 452, pp. 223-229, Sep 2014.

[34] G. Odette, "Recent Progress in Developing and Qualifying Nanostructured Ferritic Alloys for Advanced Fission and Fusion Applications," Jom, pp. $1-15$.

[35] M. Saber, W. Z. Xu, L. L. Li, Y. T. Zhu, C. C. Koch, and R. 0. Scattergood, "Size effect of primary Y203 additions on the characteristics of the nanostructured ferritic ODS alloys: Comparing asmilled and as-milled/annealed alloys using S/TEM," Journal of Nuclear Materials, vol. 452, pp. 223-229, Sep 2014.

[36] Y. J. Hu, J. Li, K. A. Darling, W. Y. Wang, B. K. VanLeeuwen, X. L. Liu, L. J. Kecskes, E. C. Dickey and Z. K. Liu, "Nano-sized Superlattice Clusters Created by Oxygen Ordering in Mechanically Alloyed Fe Alloys," Scientific Reports, Vol. 5:11772, pp. 1-9, 2015.

[37] T. B. Massalski, H. Okamoto, P. Subramanian, and L. Kacprzak, Binary alloy phase diagrams: ASM international, 1990.

[38] F. C. Campbell, Elements of metallurgy and engineering alloys: ASM International, 2008.

[39] K. A. Darling, R. N. Chan, P. Z. Wong, J. E. Semones, R. O. Scattergood, and C. C. Koch, "Grain-size stabilization in nanocrystalline FeZr alloys," Scripta Materialia, vol. 59, pp. 530-533, 2008.

[40] E. Hellstern and L. Schultz, "Formation and Properties of Mechanically Alloyed Amorphous Fe-Zr," Materials Science and Engineering, vol. 97, pp. 39-42, Jan 1988.

[41] C. Michaelsen and E. Hellstern, "Mossbauer-Effect on Mechanically Alloyed Fe-Zr Glasses," Journal of Applied Physics, vol. 62, pp. 117119, Jul 11987.

[42] E. Hellstern and L. Schultz, "Glass Forming Ability in Mechanically Alloyed Fe-Zr," Applied Physics Letters, vol. 49, pp. 1163-1165, Nov 3 1986.

[43] J. Jiang, F. W. Poulsen, and S. Mфrup, "Structure and thermal stability of nanostructured iron-doped zirconia prepared by high-energy ball milling," Journal of Materials Research, vol. 14, pp. 1343-1352, 1999.

[44] P. Ghigna, G. Spinolo, U. Anselmi-Tamburini, F. Maglia, M. Dapiaggi, G. Spina, and L. Cianchi, "Fe-doped zirconium oxide produced by selfsustained high-temperature synthesis: Evidence for an Fe-Zr direct bond," Journal of the American Chemical Society, vol. 121, pp. 301-307, 1999. 
[45] F. Maglia, U. Anselmi-Tamburini, G. Spinolo, and Z. A. Munir, "Zirconia-Based Metastable Solid Solutions through Self-Propagating High-Temperature Synthesis: Synthesis, Characterization, and Mechanistic Investigations," Journal of the American Ceramic Society, vol. 83, pp. 1935-1941, 2000.

[46] F. Legorreta Garcia, A. Peigney, and C. Laurent, "Tetragonal-(Zr, Co) 02 solid solution: Combustion synthesis, thermal stability in air and reduction in $\mathrm{H} 2, \mathrm{H} 2-\mathrm{CH} 4$ and $\mathrm{H} 2-\mathrm{C} 2 \mathrm{H} 4$ atmospheres," Materials Research Bulletin, vol. 43, pp. 3088-3099, 2008.

[47] F. J. Berry, M. H. Loretto, and M. R. Smith, "Iron-zirconium oxides: An investigation of structural transformations by X-ray diffraction, electron diffraction, and iron-57 Mössbauer spectroscopy," Journal of Solid State Chemistry, vol. 83, pp. 91-99, 1989.

[48] S. Davison, R. Kershaw, K. Dwight, and A. Wold, "Preparation and characterization of cubic ZrO< sub $>2</$ sub $>$ stabilized by Fe (III) and Fe (II)," Journal of Solid State Chemistry, vol. 73, pp. 47-51, 1988.

[49] M. Furukawa, Z. Horita, M. Nemoto, and T. G. Langdon, "Review: Processing of metals by equal-channel angular pressing," Journal of Materials Science, vol. 36, pp. 2835-2843, 2001.

[50] S. Basu and V. Sarin, "Oxidation behavior of WC-Co," Materials Science and Engineering: A, vol. 209, pp. 206-212, 1996.

[51] R. Haubner, M. Wilhelm, R. Weissenbacher, and B. Lux, Boron nitridesproperties, synthesis and applications: Springer, 2002.

[52] T. B. Massalski, "ASM Binary alloy phase diagrams $2^{\text {nd }}$ edition," ASM International, vol. 2, pp. 1737, 1990.

[53] F. Vurpillot, A. Bostel, D. Blavette. Trajectory overlaps and local magnification in three-dimensional atom probe, Applied Physics Letters 76 (2000) 3127-3129.

[54] M. W. Phaneuf, "Applications of focused ion beam microscopy to materials science specimens," Micron, vol. 30, pp. 277-288, Jun 1999.

[55] J. S. C. Jang and C. C. Koch, "The hall-petch relationship in nanocrystalline iron produced by ball milling," Scripta Metall. Mater. , vol. 24, pp. 1599-1604, 1990.

[56] Q. Wei, L. Kecskes, T. Jiao, K. Hartwig, K. Ramesh, and E. Ma, "Adiabatic shear banding in ultrafine-grained Fe processed by severe plastic deformation," Acta Materialia, vol. 52, pp. 1859-1869, 2004.

[57] K. T. Ramesh, Nanomaterials: Springer, 2009.

[58] 0. C. Hellman, J. A. Vandenbroucke, J. Rusing, D. Isheim, D. N. Seidman, "Analysis of Three-dimensional Atom-probe data by the proximity histogram," Microscopy and Microanalysis, vol. 6 pp. 437$444,2000$.

[59] H. Kotan, K. A. Darling, M. Saber, R. O. Scattergood, and C. C. Koch, "An in situ experimental study of grain growth in a nanocrystalline $\mathrm{Fe}_{91} \mathrm{Ni}_{8} \mathrm{Zr}_{1}$ alloy," Journal of Materials Science, vol. 48, pp. 22512257, 2013.

[60] H. Kotan, K. A. Darling, M. Saber, R. O. Scattergood, and C. C. Koch, "Thermal stability and mechanical properties of nanocrystalline $\mathrm{Fe}-\mathrm{Ni}-\mathrm{Zr}$ alloys prepared by mechanical alloying," Journal of Materials Science, vol. 48, pp. 8402-8411, 2013. 
[61] H. Kotan, K. A. Darling, M. Saber, C. C. Koch and R. O. Scattergood, "Effect of zirconium on grain growth and mechanical properties of a ball-milled nanocrystalline FeNi alloy," Journal of Alloys and Compounds, vol. 551, pp. 621-629, 2013.

[62] K. Clemons, C. Lorraine, G. Salgado, A. Taylor, J. Ogren, P. Umin, and 0 . S. Es-Said, "Effects of heat treatments on steels for bearing applications," Journal of Materials Engineering and Performance, vol. 16, pp. 592-596, 2007.

[63] G. E. Dieter and D. Bacon, Mechanical metallurgy vol. 3: McGraw-Hill New York, 1986.

[64] M. A. Atwater, D. Roy, K. A. Darling, B. G. Butler, R. O. Scattergood, and C. C. Koch, "The thermal stability of nanocrystalline copper cryogenically milled with tungsten," Materials Science and Engineering a-Structural Materials Properties Microstructure and Processing, vol. 558, pp. 226-233, Dec 152012. 

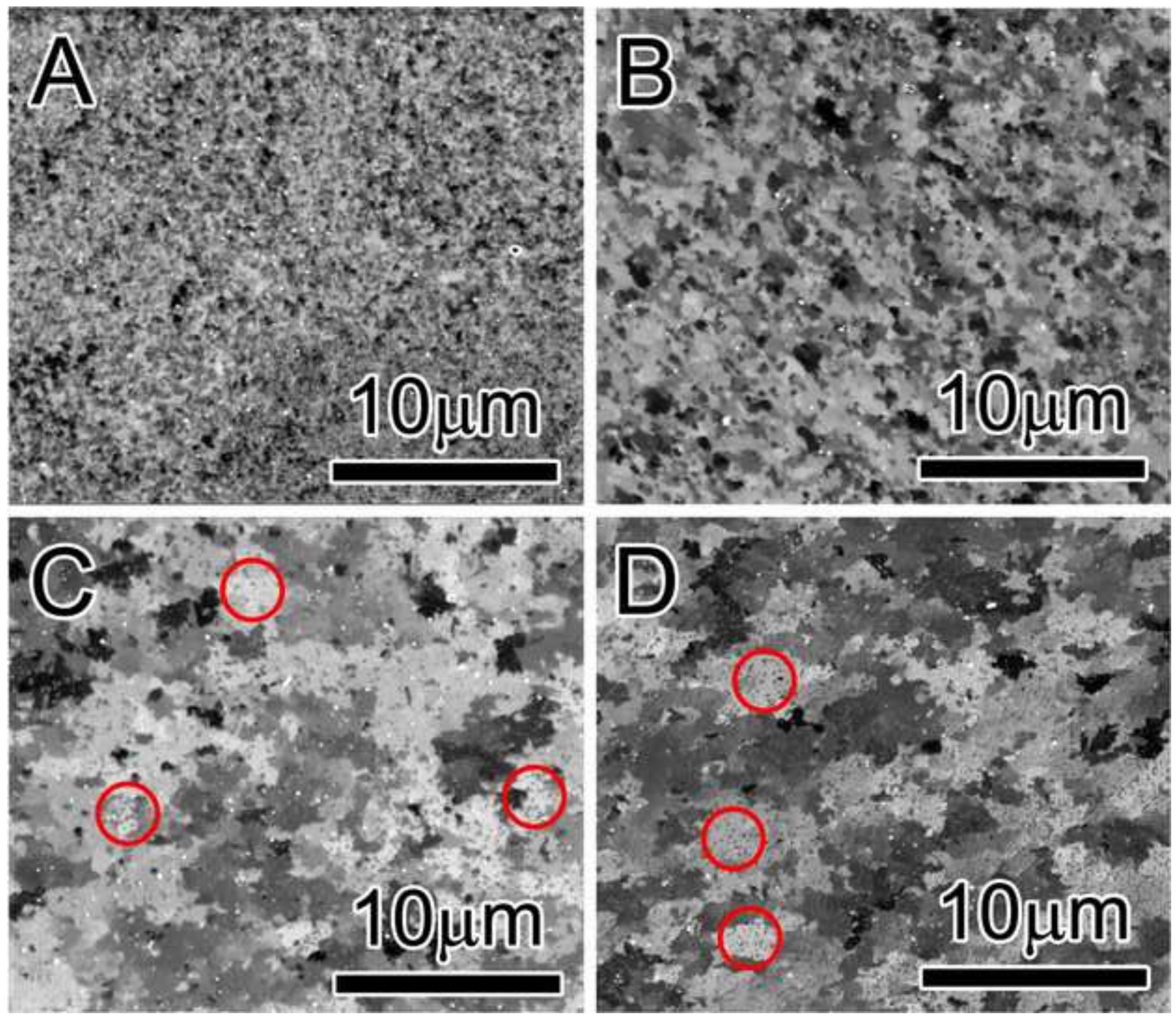


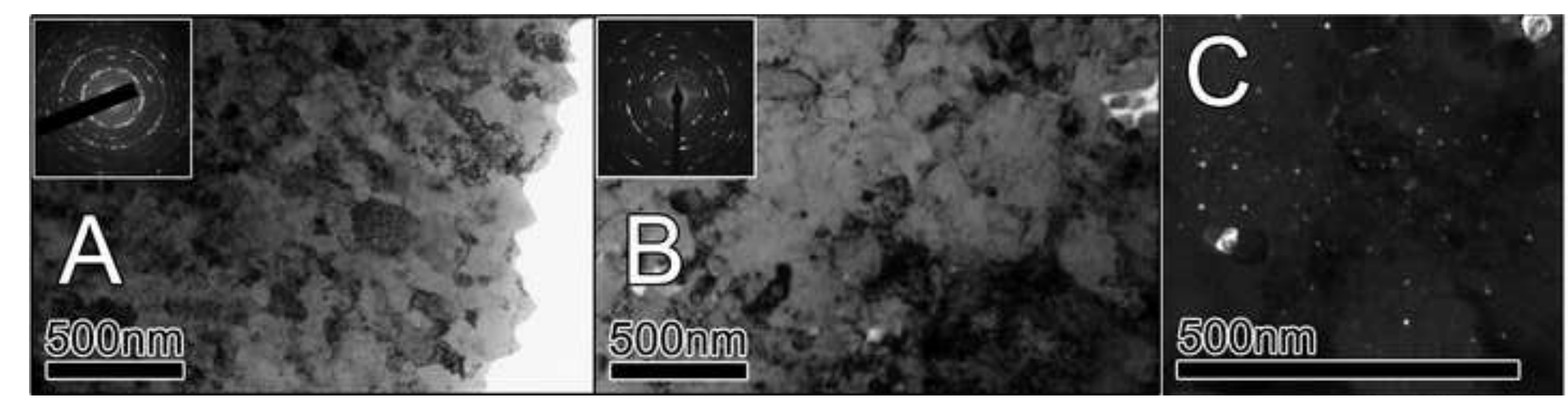

500 nn 

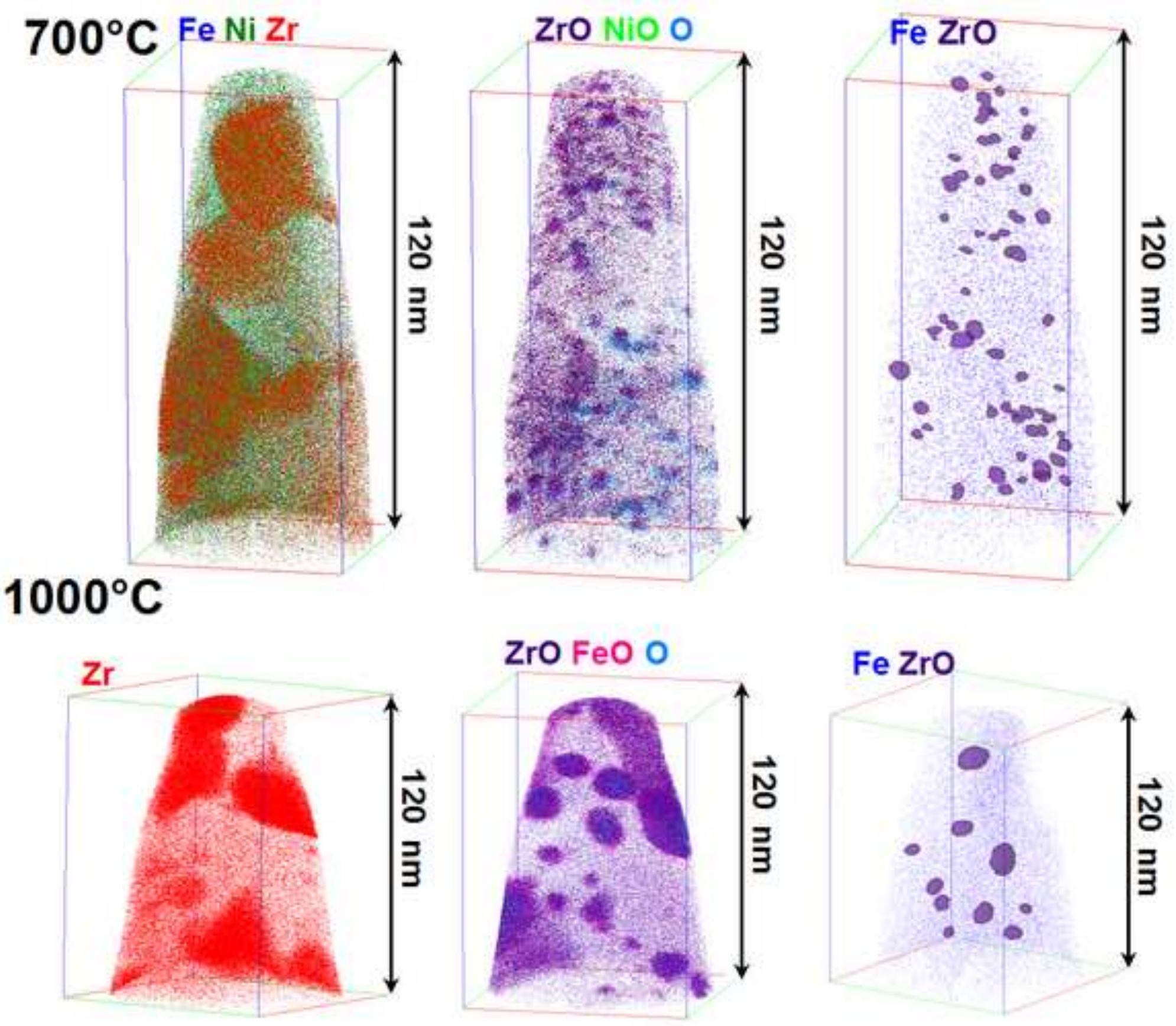

Fe Zro

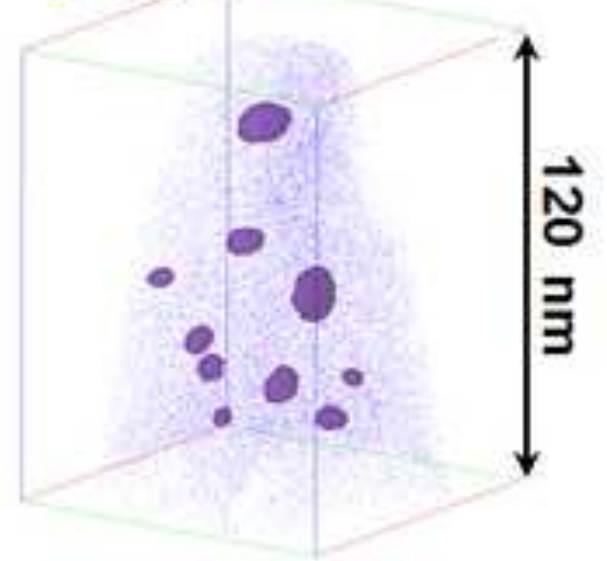

(a)

(b)

(c) 

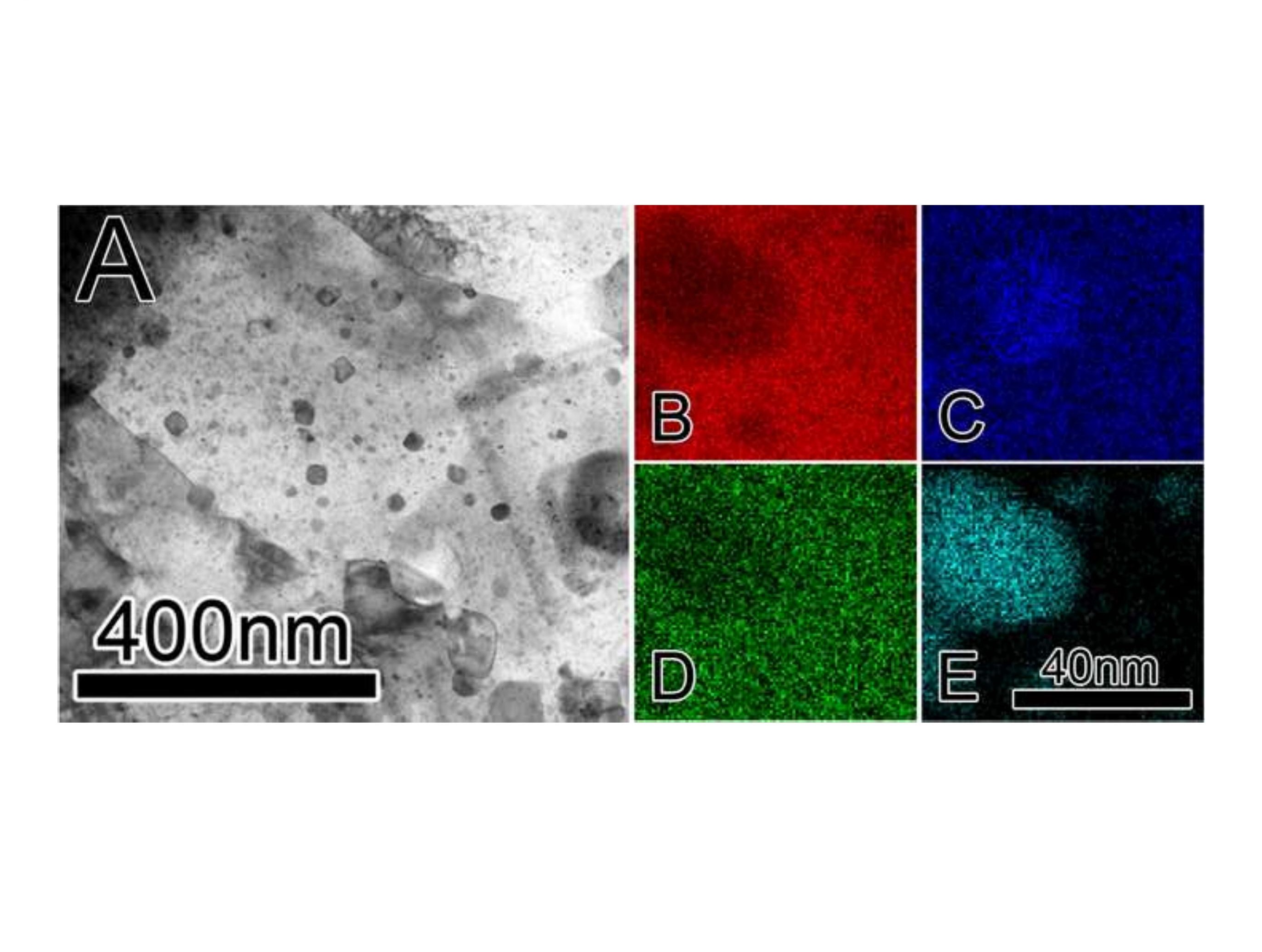
$\mathrm{Fe} \mathrm{ZrO}$
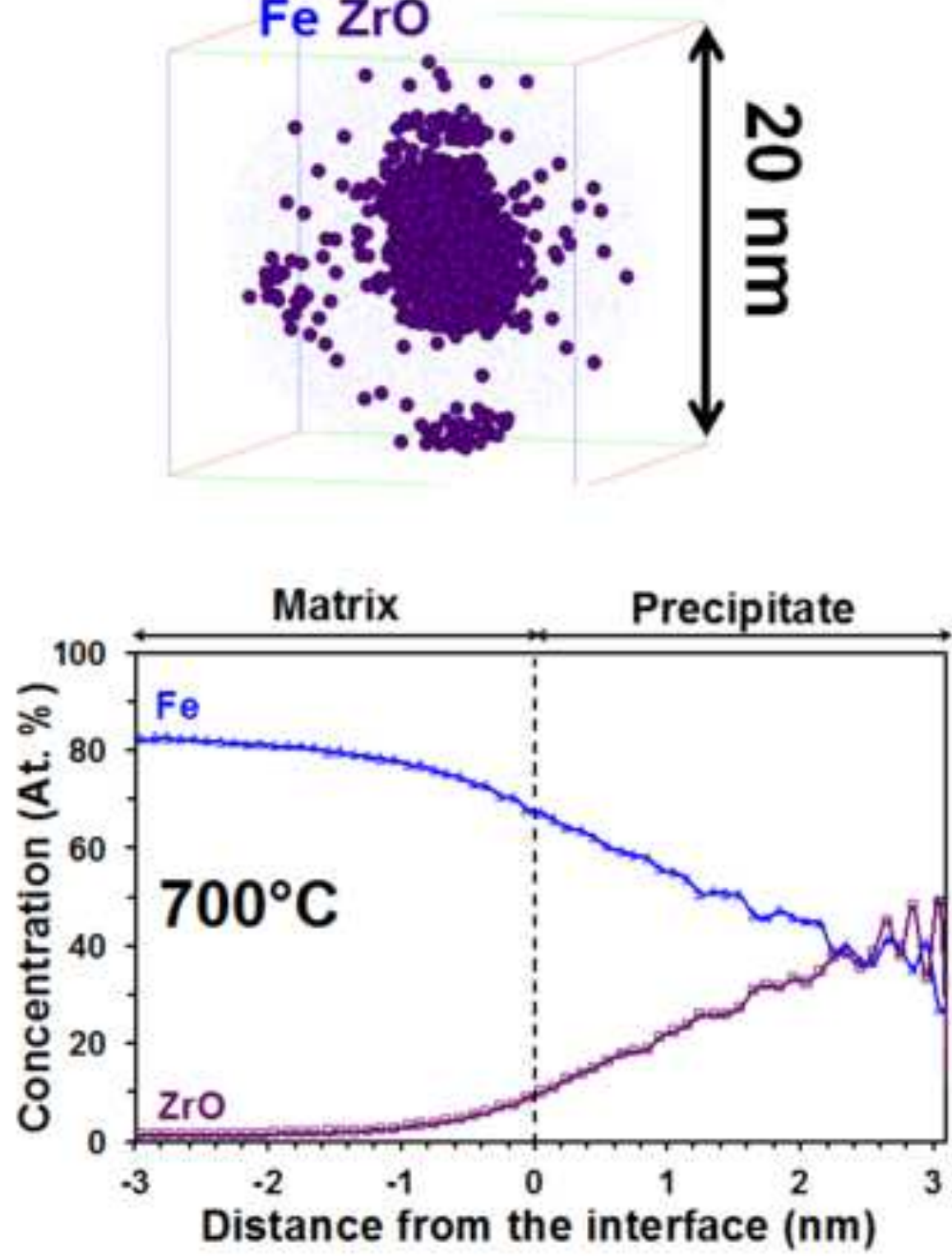

(a)
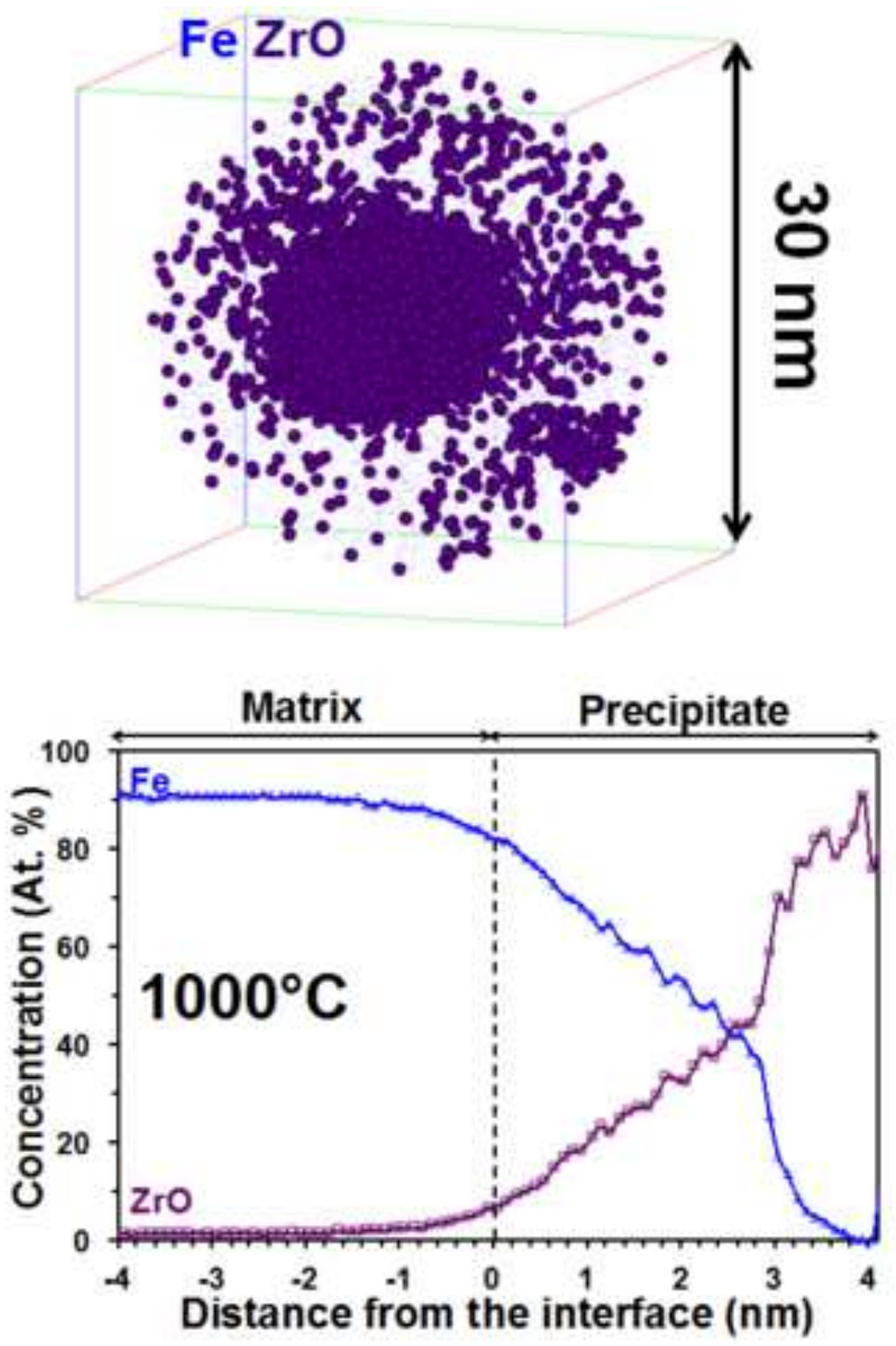

(b) 


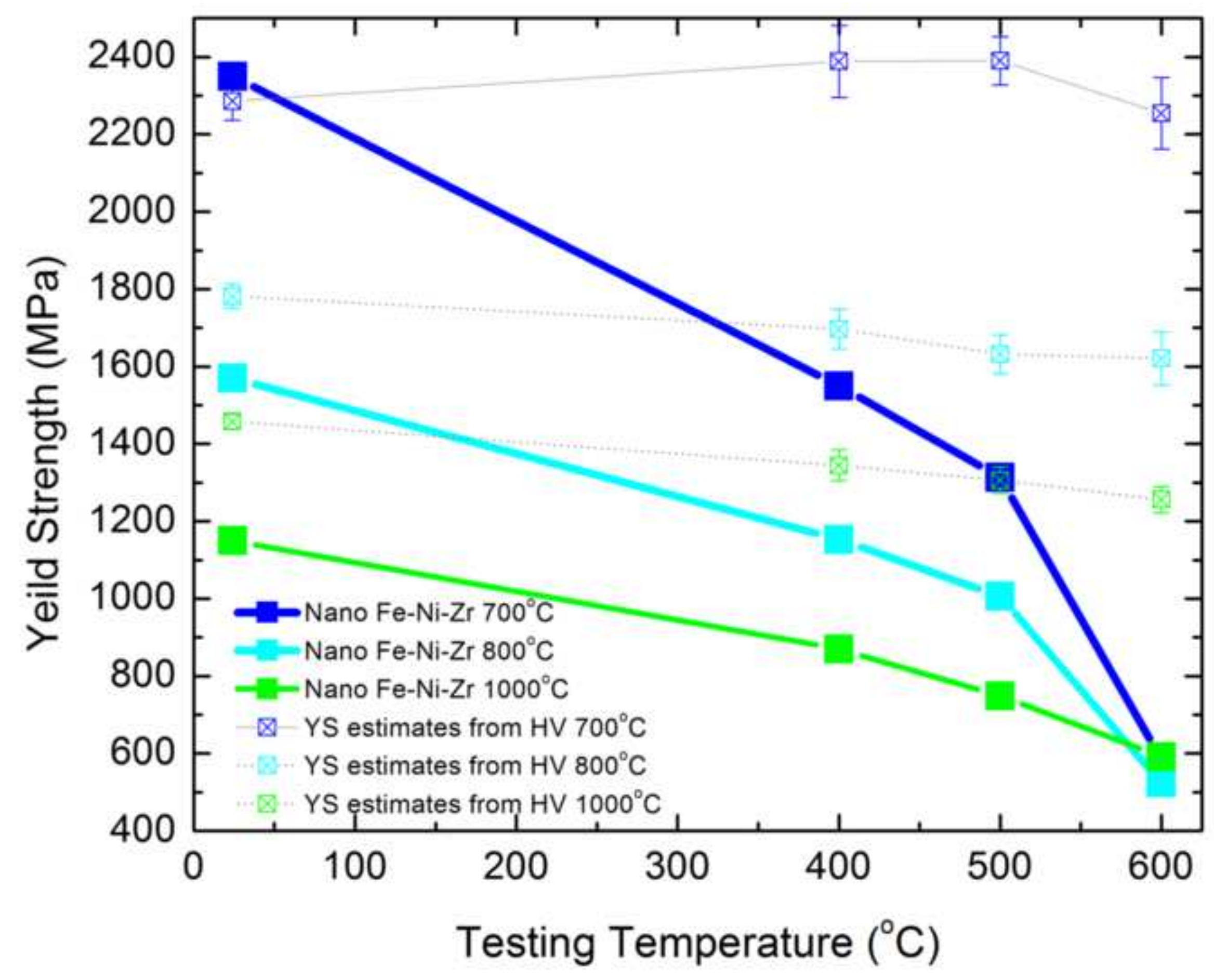




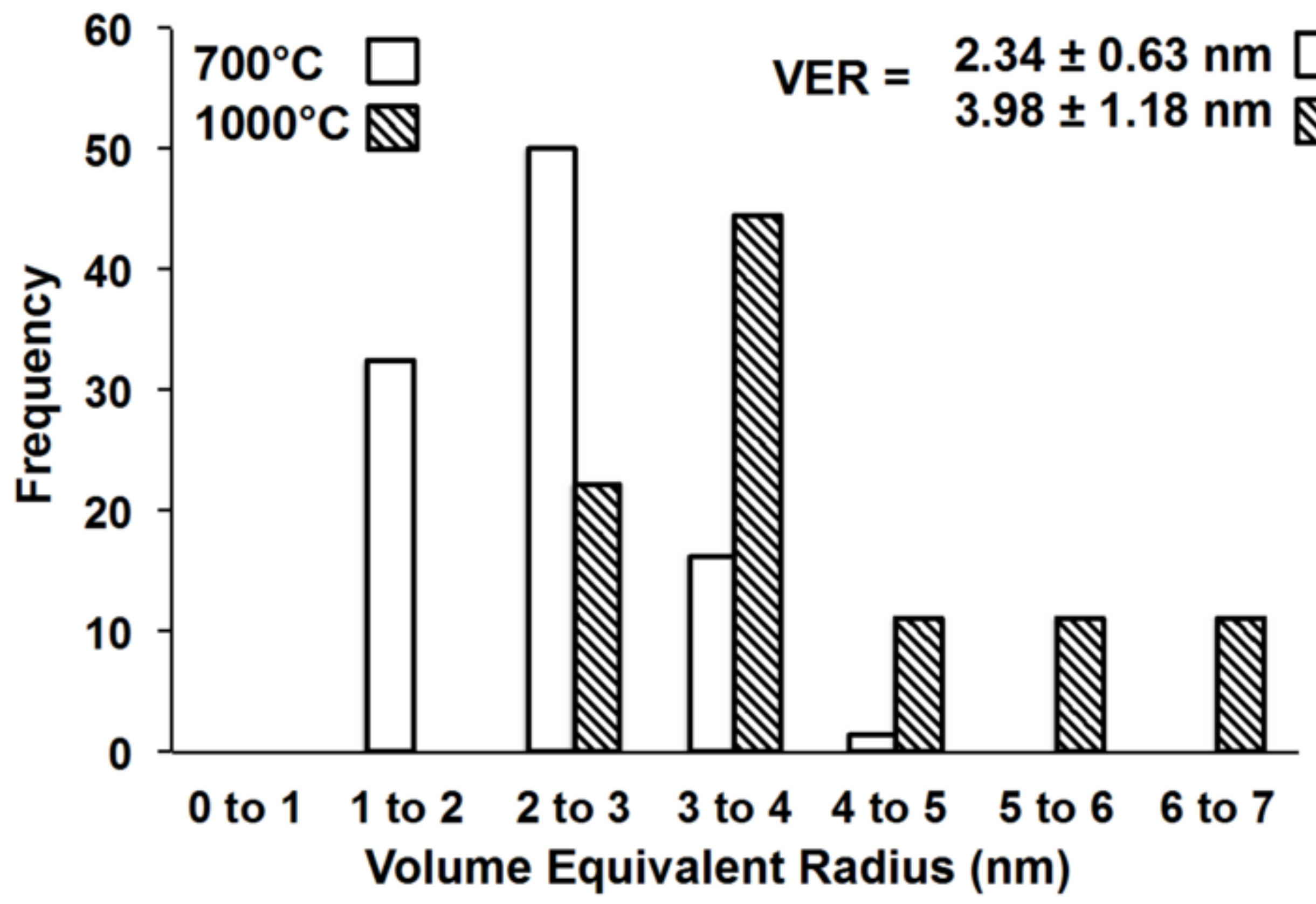

